\title{
DEVELOPMENT OF COLD-ADAPTED RECOMBINANT LIVE, ATTENUATED INFLUENZA A VACCINES IN THE U.S.A. AND U.S.S.R.
}

\author{
ALAN P. KENDAL ${ }^{1}$, HUNEIN F. MAASSAB ${ }^{2}$, GALINA I. ALEXANDROVA ${ }^{3}$ and YURI $Z$. \\ GHENDON $^{4}$
}

${ }^{1}$ Center for Infectious Disease, Centers for Disease Control, U.S. Public Health Service, Bldg 7, Room 112, 1600 Clifton Road, Atlanta, GA 30333; ${ }^{2}$ School of Public Health, University of Michigan, Ann Arbor, MI, U.S.A.; ${ }^{3}$ Institute for Experimental Medicine, Academy of Medical Sciences, Lengingrad; ${ }^{4}$ Research Institute for Viral Preparations, Moscow, U.S.S.R.

(Received 1 July 1981; accepted 17 August 1981)

influenza A viruses recombinant, cold-adapted, live attenuated viruses

\section{INTRODUCTION}

Influenza remains a major public health problem in many countries. Periodic epidemics disrupt economic and social activities within entire communities, impose sudden large demands on available medical facilities, and can cause excess mortality, particularly in the elderly or those with certain chronic illnesses $[5,7,21]$.

Vaccination can provide significant protection against infection and illness during natural epidemics, but this protection is usually considered to be of limited duration, particularly due to the changes in antigenic specificity of influenza virus surface glycoproteins (hemagglutinin (HA) and neuraminidase (NA)) which continually occur [58] . This problem affects the two methods that exist for influenza vaccination. Inactivated (killed) vaccines must be constantly updated to include newer strains, which in any event often induce maximum antibody responses not to themselves but to previously prevalent strains, as expounded in the 'Doctrine of Original Antigenic Sin' $[48,62]$. Live, attenuated virus vaccines might be expected to produce a more long-lasting protection than inactivated vaccines on the assumption that they would mimic natural infection which, for unknown reasons, probably protects longer than inactivated vaccines [15]. However, live vaccines must be infectious, attenuated, induce protective immunity and be genetically stable, a combination of properties that might not be obtained in a short space of time with each important new strain (antigenic variant) as it appears.

The ability to recombine influenza viruses by mixed infections during which the segmented RNA genome can reassort [52] raised the prospect that once a suitable attenuated vaccine strain of influenza $A$ was prepared, this property could be transferred to a new strain with contemporary HA and NA antigens $[8,35,37]$. Provided only that these glycoproteins did not contribute significantly to other (non-antigen dependent) 
vaccine-required properties, attenuated recombinants should be rapidly obtained in this way.

This strategy has been adopted now, using several prospective attenuated strains as donors in recombinations with contemporary wild-type $(w t)$ viruses. The work with highly laboratory-passaged attenuated strains, such as A/PR/8/34 (H1N1) or A/Okuda/ 57 (H2N2), has been described elsewhere $[10,16,39,47,57]$. Although subjected to extensive clinical studies, and in some cases commercially dsitributed, these vaccines are not currently being used except for occasional special research investigations. A second approach to the use of recombinant live virus vaccines was that of Chanock and coworkers, who followed a suggestion by Mackenzie [37] that temperature-sensitive $(t s)^{*}$ variants might be attenuated. Methods were developed for introducing one or more single step lesions into influenza viruses and then transferring the $t s$ genes to new wt strains by recombination. Although the two most widely studied ts donors (TS 1-E and TS 1-A-2) had many desirable properties for live vaccine use, instability of the phenotypic $t s$ marker (associated in at least one case with reversion to virulence) proved a major obstacle [60].

A third alternative in the preparation of recombinant live virus vaccines is the use of cold-adapted $(c a)$ viruses as attenuated donor strains. This concept has been studied in the Soviet Union since at least 1965 [4] where in many years $c a$ influenza viruses have been empirically selected for use in widespread vaccination activities. Because of the reported success in the Soviet Union with ca live vaccines, research in this area has been undertaken also in the United States, including investigation of methods for obtaining such variants and testing their biological properties in vitro [30], in animal models [32] and in some preliminary human volunteer studies [9]. In both countries there has been active application of genetic recombination (reassortment) and of newly developed molecular techniques, to analyze the properties of donor-attenuated $c a$ viruses and their recombinants as an aid to the development of live, attenuated influenza vaccines. These recent advances are the subject of this review.

\section{DONOR-ATTENUATED STRAINS}

\section{Method of obtaining donor-attenuated strains}

In the U.S.S.R. and the U.S.A. a large number of field strains of influenza A viruses of different subtypes have been adapted to growth at suboptimal temperatures $\left(<30^{\circ} \mathrm{C}\right)$ as a potential method for attenuating the virus' virulence $[1,4,30,31,34,54]$. Only a small number of these strains, however, have been used in recombination experiments designed to transfer the cold-adaptation property to candidate vaccines for human use. In the U.S.S.R. these donor strains consist of A/Leningrad/9/46(H1N1) and A/Leningrad/134/

\footnotetext{
* $t s$ is used to designate viruses exhibiting $>10^{3} \log _{10}$ reduction in infectious titer at non-permissive temperatures of $>38^{\circ} \mathrm{C}$ compared to titer at permissive temperature of $33-34^{\circ} \mathrm{C}$.
} 
57(H2N2) [4] , and in the U.S.A. most recombination studies have used A/Ann Arbor/ $6 / 60(\mathrm{H} 2 \mathrm{~N} 2)$ as the $c a$ donor parent.

Prior to adaptation to growth at $25^{\circ} \mathrm{C}$, the Leningrad viruses received 20 or more chick embryo (egg allantoic cavity) passages at $32^{\circ} \mathrm{C}$. Subsequently they were passaged $17-47$ times in eggs at $25-26^{\circ} \mathrm{C}$ for 4 or 5 days. During the cold-adaptation procedure, it was twice necessary to passage the $\mathrm{H} 2 \mathrm{~N} 2$ virus at $31^{\circ} \mathrm{C}$ for 2 days to maintain viability and later passages were at $26^{\circ} \mathrm{C}$ for 4 days rather than $25^{\circ} \mathrm{C}$ for 5 days, with higher yield obtained [4]. Experience in the U.S.A., starting with viruses that had fewer egg passages at $32^{\circ} \mathrm{C}$, was consistent that field strains of influenza did not normally contain $c a$ mutants capable of replicating efficiently at $25^{\circ} \mathrm{C}$. Accordingly, a procedure of stepwise adaptation to growth at lower temperatures was adopted. A field strain of $\mathrm{H} 2 \mathrm{~N} 2$ influenza, A/Ann Arbor/6/60, was isolated in primary chicken kidney (CK) cells and then passaged 10 times in $\mathrm{CK}$ cells at $33^{\circ} \mathrm{C}$ and 10 times at $30^{\circ} \mathrm{C}$. Although on initial passage at $30^{\circ} \mathrm{C}$ the virus yield was $2-3$ logs lower than at $33^{\circ} \mathrm{C}$, after 10 passages at this temperature virus was selected that grew equally efficiently at $30^{\circ} \mathrm{C}$ as the original field strain had done at $33^{\circ} \mathrm{C}$. This process of progressive adaptation was repeated by growing the mutant at $27^{\circ} \mathrm{C}$ for 10 passages and finally at $25^{\circ} \mathrm{C}$ for 10 passages (Table 1). It should be noted that this line of $c a$ A/Ann Arbor/6/60 differs from that developed for evaluation in an animal model [30] in its lower number of CK passages, and absence of mouse lung passages, prior to adaptation to growth at $25^{\circ} \mathrm{C}$.

\section{Biological properties of donor-attenuated strains}

The $c a$ A/Ann Arbor/6/60 mutant and the Leningrad $c a$ mutants selected for high growth at temperatures below $30^{\circ} \mathrm{C}$ shared the property of restricted replication in embryonated eggs at the elevated temperature of $39-40^{\circ} \mathrm{C}$ (Table 2). Characterization of replication of the $c a \mathrm{~A} / \mathrm{Ann}$ Arbor/6/60 virus has been done not only in embryonated eggs, but also by plaque titration in primary CK cells. No detectable plaques are produced

\section{TABLE 1}

Isolation and passage history of cold-adapted influenza A/Ann Arbor/6/60 mutant used for preparing recombinant vaccine candidates

\begin{tabular}{ll}
\hline Passage level & Conditions \\
\hline 1 & Throat swab, incubate at $36^{\circ} \mathrm{C}$ in $\mathrm{CK}$ cells \\
2 & $\mathrm{CK}_{1}$ isolate, incubate at $36^{\circ} \mathrm{C}$ in $\mathrm{CK}$ cells \\
$3-9$ & Serial passages, incubate at $33^{\circ} \mathrm{C}$ in $\mathrm{CK}$ cells \\
$10-16$ & Serial passages, incubate at $30^{\circ} \mathrm{C}$ in CK cells \\
$17-23$ & Serial passages, incubate at $25^{\circ} \mathrm{C}$ in CK cells \\
$23-29$ & Serial plaque purification, at $25^{\circ} \mathrm{C}$ in CK cells \\
$30-32^{\mathrm{a}}$ & Serial passage at $25^{\circ} \mathrm{C}$ in specific pathogen-free hens' eggs \\
\hline
\end{tabular}

a Recombinants prior to AA-CR 22 were prepared from a stock passaged in standard hens' eggs. 


\section{TABLE 2}

Replication temperature markers of cold-adapted viruses used as parents in the preparation of recombinant vaccine candidates

\begin{tabular}{|c|c|c|c|c|c|c|c|}
\hline & \multicolumn{7}{|c|}{ Replication of cold-adapted parental virus } \\
\hline & \multicolumn{4}{|c|}{ in eggs a at $\left({ }^{\circ} \mathrm{C}\right)$} & \multicolumn{3}{|c|}{ in $\mathrm{CK}$ cells $\mathrm{b}$ at $\left({ }^{\circ} \mathrm{C}\right)$} \\
\hline & 25 & 28 & 33 & $\overline{39-40}$ & $\overline{25}$ & 33 & 39 \\
\hline A/Leningrad/9/46(H1N1) & 2.25 & 8.25 & 8.25 & 2.25 & $\mathrm{ND}^{\mathrm{c}}$ & ND & ND \\
\hline A/Leningrad/134/57(H2N2) & 4.75 & 8.25 & 8.25 & 2.25 & ND & ND & ND \\
\hline A/Ann Arbor/6/60(H2N2) & 7.50 & ND & 8.50 & 1.30 & 8.30 & 8.70 & $<3.0$ \\
\hline
\end{tabular}

a EID Ev $_{50}\left(\log _{10}\right)$ after $2-3$ days at $33^{\circ} \mathrm{C}$ or $39^{\circ} \mathrm{C}$ and after 5 days at $25^{\circ} \mathrm{C}$.

b Plaque-forming units $\left(\log _{10}\right)$ after $3-4$ days at $25^{\circ} \mathrm{C}, 33^{\circ} \mathrm{C}$ or $39^{\circ} \mathrm{C}$, and after $5-7$ days at $25^{\circ} \mathrm{C}$.

c Not done.

at $39^{\circ} \mathrm{C}$ in contrast to the wild-type (wt) virus. Similar results are obtained in MadinDarby canine kidney (MDCK) cell cultures (not shown). The ca mutant, but not the wt A/Ann Arbor $/ 6 / 60$ virus, also produces plaques in primary CK cells at $25^{\circ} \mathrm{C}$, which provides a convenient mechanism for preparing $c a$ recombinants, as described below.

Another biological property analyzed for the $c a \mathrm{~A} / \mathrm{Ann}$ Arbor/6/60 virus is its virulence in the ferret animal model system. The $w t$ virus replicates to a higher titer than its $c a$ derivative and is isolated from lungs as well as turbinates (Table 3). Greater replication of the $w t$ virus is accompanied by a febrile response and the production of purulent rhinitis which are not produced by infection with the $c a$ mutant.

\section{Detection of genetic mutations in donor ca virus strains}

Most work has been directed towards determining the genetic basis for the ts phenotype of the $c a$ viruses. Traditionally, determination of the gene possessing the conditional lethal $t s$ lesion in one mutant microorganism has been determined by analyzing the ability of the mutant to complement or recombine with other $t s$ mutants whose lesions

TABLE 3

Replication of wild-type and cold-adapted A/Ann Arbor/6/60 virus in ferrets ${ }^{a}$

\begin{tabular}{llllll}
\hline $\begin{array}{l}\text { Time post- } \\
\text { infection (h) }\end{array}$ & \multicolumn{2}{l}{ Infectivity titer } & & & \\
\cline { 2 - 6 } & Wild-type & & & Mutant & Lungs \\
\cline { 2 - 6 } & Turbinates & & Turbinates & Lungs \\
\hline 48 & 5.7 & 1.7 & 4.3 & $<1.0$ \\
96 & 5.5 & 2.5 & 3.5 & $<1.0$ \\
192 & 3.5 & 1.0 & $<1.0$ & $<1.0$ \\
\hline
\end{tabular}

a Ferrets were infected intranasally with about $10^{7.5}$ EID $_{50}$ of virus.

b $\log _{10} E_{\text {ID }} / \mathrm{ml}$ of $20 \%$ tissue suspension. 
have been previously defined. Because influenza viruses have a segmented genome, reassortment of individual RNA segments can occur in mixed infections analogous to recombination, so that both recombination and complementation analyses of $t s$ lesions are possible.

Each of the ca Leningrad donor viruses has been examined by recombination analysis with a set of six previously characterized fowl plague virus $t s$ mutants which have singlestep ts lesions in genes coding for their internal proteins [6,18-20,24,38]. The A/ Leningrad/9/46 (H1N1) virus failed to recombine with fowl plague mutants possessing lesions in the P3 gene (RNA 1), the P1 gene (RNA 2) and the matrix protein gene suggesting the presence of mutations in these three genes in the $c a$ Leningrad strain (Table 4). The $c a$ A/Leningrad/134/57(H2N2) virus, passaged at $25^{\circ} \mathrm{C} 17$ times, failed to recombine with fowl plague virus mutants having lesions in genes coding for P1, nucleoprotein, and matrix protein, also suggesting the existence of mutations in three genes in this Leningrad $c a$ virus. After a further 30 passages at $25^{\circ} \mathrm{C}$, the $\mathrm{A} /$ Leningrad $/ 134 / 57$ $c a$ virus additionally lost the ability to recombine with mutants possessing $t$ lesions in the P1 gene (RNA 2) and the non-structural protein gene (RNA 8), so that in this more highly passaged virus a total of five genes may contain ts lesions. Due to possible incompatibilities between certain gene constellations that can, for example, prevent the detection of non-ts recombinants in some host systems [53], definitive proof of the site of ts mutations (as with ca A/Ann Arbor/6/60) will require further detailed genetic and molecular analysis.

The $c a$ A/Ann Arbor/6/60 mutant has been analyzed by complementation analysis with a series of single-step $t s$ mutants prepared by Murphy and colleagues $[45,56]$ and by recombination analysis with single-step $t s$ mutants prepared by Sugiura and colleagues [59]. In the former case it was found that the ca mutant failed to comple-

\section{TABLE 4}

Genetic analyses of cold-adapted ( $c a$ ) Leningrad virus by recombination analysis with mutants of influenza A fowl plague virus (Dobson Weybridge strain) having $t s$ lesions in single genes

\begin{tabular}{|c|c|c|c|c|}
\hline \multicolumn{2}{|c|}{ FPV mutants } & \multicolumn{3}{|c|}{ Recombination frequency with $c a$ virus } \\
\hline \multirow[t]{2}{*}{ Clone } & \multirow{2}{*}{$\begin{array}{l}\text { Protein with } \\
t s \text { mutation }\end{array}$} & \multirow{2}{*}{$\frac{\mathrm{A} / \text { Leningrad/9/46(H1N } 1)}{25^{\circ} \mathrm{C} \times 37^{\mathrm{a}}}$} & \multicolumn{2}{|c|}{ A/Leningrad/134/57(H2N2) } \\
\hline & & & $25^{\circ} \mathrm{C} \times 17^{\mathrm{a}}$ & $25^{\circ} \mathrm{C} \times 47^{\mathrm{a}}$ \\
\hline $29^{b}$ & P3 & $<0.01$ & $<0.01$ & $<0.01$ \\
\hline $131^{b}$ & P1 & $<0.01$ & 22 & $<0.01$ \\
\hline $166^{\mathrm{b}}$ & $\mathrm{P} 2$ & 1.7 & 8.0 & 2.0 \\
\hline US1 ${ }^{c}$ & NP & 1.2 & $<0.01$ & $<0.01$ \\
\hline $3031^{b}$ & $\mathbf{M}$ & $<0.01$ & $<0.01$ & $<0.01$ \\
\hline $\mathrm{mN} 3^{\mathrm{c}}$ & NS & 15 & 4.0 & $<0.01$ \\
\hline
\end{tabular}

a Number of times passaged at $25^{\circ} \mathrm{C}$.

b Described in refs. 18-20, 24, 38 .

c Described in ref 1 . These mutants were kindly supplied by Dr. B. Mahy. 
ment a virus R1 [54], which has a defect in its P3 protein [49], although complementation did occur with $t s$ mutants from six other genetic groups. Recombination experiments comparing mutant A/Ann Arbor/6/60 with Sugiura's ts mutants of WSN virus, however, showed that the A/Ann Arbor/6/60 mutant could recombine with the WSN mutant having a lesion in its P3 protein, but could not recombine with a WSN mutant having a lesion in its $P 1$ protein [13].

To resolve these contradictory findings, the genome composition was determined for several recombinants derived from the $c a$ A/Ann Arbor/6/60 virus. The surprising result was obtained (Table 5) that every gene of mutant A/Ann Arbor/6/60 was present in one or more non-ts recombinant viruses. This indicated that possibly no single gene contained a $t s$ lesion in the $c a$ mutant, but rather a combination of two or more of its genes was necessary to obtain a $t s$ phenotype. The non-ts recombinant (S34) was found to contain a single $w t$ gene (P3, coded by RNA 1), showing that this gene of the mutant A/Ann Arbor/6/60 was one of those involved in the group of genes necessary for a $t s$ phenotype. Examination of recombinants having either $t s$ or non-ts phenotypes indicated that when. ever the A/Ann Arbor/6/60 P3 and matrix proteins segments were present in the virus, the virus was ts. Thus, it is suggested that the $t$ phenotype of mutant A/Ann Arbor/6/60

\section{TABLE 5}

Properties of recombinants derived from mixed infections of A/Ann Arbor/6/60 mutant and WSN mutants or A/Ann Arbor/9/73 wild-type

\begin{tabular}{|c|c|c|c|c|c|c|c|c|c|}
\hline \multirow{2}{*}{$\begin{array}{l}\text { Recombinant clone } \\
\text { designation }^{\mathrm{a}}\end{array}$} & \multicolumn{8}{|c|}{ Gene derivation $\mathbf{b}$} & \multirow{2}{*}{$\begin{array}{l}\text { EOP }(\%) \\
\text { p.f.u. } 39^{\circ} \mathrm{C} / \\
\text { p.f.u. } 33^{\circ} \mathrm{C}\end{array}$} \\
\hline & $\begin{array}{l}\text { P3 } \\
\text { (RNA 1) }\end{array}$ & $\begin{array}{l}\text { P1 } \\
\text { (RNA 2) }\end{array}$ & $\begin{array}{l}\text { P2 } \\
\text { (RNA 3) }\end{array}$ & HA & NP & NA & $\mathbf{M}$ & NS & \\
\hline $\mathrm{Ia}_{3}$ & $\mathbf{A}$ & $\mathbf{A}$ & W & w & A & A & w & A & 12 \\
\hline $\mathrm{Iu}_{2}$ & A & W & W & W & w & $\mathbf{A}$ & w & W & 67 \\
\hline $\operatorname{Im}_{3}$ & $A$ & W & W & w & A & A & w & $\mathbf{A}$ & 25 \\
\hline $\operatorname{llg}_{1}$ & $\mathbf{A}$ & W & $\mathbf{A}$ & A & $\mathbf{A}$ & $\mathbf{A}$ & w & $\mathbf{A}$ & 25 \\
\hline $\mathrm{Vh}_{5}$ & w & $\mathbf{W}$ & $\mathbf{A}$ & W & $\mathbf{A}$ & W & w & W & 50 \\
\hline VIII $_{1}$ & w & w & w & $\mathbf{A}$ & w & $\mathbf{A}$ & $\mathbf{A}$ & w & 100 \\
\hline VII $_{1}$ & w & $\mathbf{A}$ & W & W & W & A & $\mathbf{A}$ & $\mathbf{A}$ & 25 \\
\hline S32 & 0 & o & $\mathbf{A}$ & $\mathbf{A}$ & $\mathbf{A}$ & A & $\mathbf{A}$ & $\mathbf{A}$ & 51 \\
\hline S34 & $\mathrm{o}$ & $A$ & $\mathbf{A}$ & A & A & $\mathbf{A}$ & $\mathbf{A}$ & $\mathbf{A}$ & 19 \\
\hline S1 & A & $\mathrm{o}$ & $\mathrm{O}$ & $o$ & 0 & A & $\mathbf{A}$ & $\mathbf{A}$ & $<0.001$ \\
\hline$S 10$ & $\mathbf{A}$ & $\mathbf{A}$ & $\mathbf{A}$ & $\mathbf{A}$ & A & A & $\mathbf{A}$ & 0 & $<0.002$ \\
\hline M4 & $\mathbf{A}$ & $\mathrm{O}$ & $\mathbf{A}$ & $\mathrm{O}$ & $\mathbf{A}$ & 0 & $\mathbf{A}$ & $\mathbf{A}$ & $<0.002$ \\
\hline
\end{tabular}

No $t s^{+}$recombinants with A/Ann Arbor/6/60 gene:

$$
\begin{array}{llllllll}
4 / 9 & 3 / 9 & 4 / 9 & 4 / 9 & 6 / 9 & 8 / 9 & 4 / 9 & 6 / 9
\end{array}
$$

No $t s$ recombinants with A/Ann Arbor/6/60 gene:

$\begin{array}{llllllll}3 / 3 & 1 / 3 & 2 / 3 & 1 / 3 & 2 / 3 & 2 / 3 & 3 / 3 & 2 / 3\end{array}$

$a, b_{A}$ indicates the gene derived from the A/Ann Arbor/6/60 mutant; $W$ indicates the gene derived from a WSN mutant; $O$ indicates the gene derived from the A/Ann Arbor/9/73 wild-type virus. 
results from synergism between these two viral proteins [13]. These findings do not exclude the possibilities that additional A/Ann Arbor/6/60 genes may affect the overall level of temperature sensitivity, or that the constellation of genes required for temperature sensitivity may vary depending on the $w t$ parent used in recombination.

The existence of mutations in all of the genes of $c a$ A/Ann Arbor/6/60 virus has been detected by a combination of different biochemical techniques [11]. For example, comparison of RNA oligonucleotide maps indicated the existence of at least five detectable differences between the $w t$ and $c a$ A/Ann Arbor/6/60 viruses in the approximately $10 \%$ of the genome that is analyzed by this procedure (Fig. 1). One spot difference occurred in each of the RNA segments RNA 1 (P3), 3 (P2) and 4 (HA), and two spot differences occurred in the nucleoprotein gene.

The presence of mutations in genes coding for HA, NA, nucleoprotein, matrix protein and non-structural protein was determined by electrophoresis of heteroduplex RNAs prepared between $w t$ virion RNA and $c a$ virus complementary RNA as described by Hay et al. [23], and existence of a mutation in RNA 2 (P1 gene) has been found by analysis of temperature sensitivity of virion transcriptase activity in recombinants of known genotype [26]. The multi-step nature of mutations in ca A/Ann Arbor/6/60 may explain the peculiarities of its reactions in complementation and recombination analyses.

Biochemical studies have failed, however, to uncover any marker which might explain the virus' temperature sensitivity of replication. All detectable polypeptides of the A/Ann Arbor/6/60 ca virus are synthesized with the same efficiency at the non-permissive temperature of $39^{\circ} \mathrm{C}$ as is observed with the $w t$ virus when tested in either CK or MDCK cell cultures, although an altered migration rate of polypeptide P2 has been observed [11]. The findings suggest that the mutation responsible for temperature sensitivity affects a late function in viral replication rather than any of the functions occurring prior to transcription of virion RNA into messenger RNAs and their translation into viral polypeptides.

\section{Infectiousness, reactogenicity and immunogenicity of donor-attenuated strains}

These properties have been examined for both of the $c a$ Leningrad viruses by infection of susceptible children. A total of 5164 children between the ages of 1 and 6 years old have been infected with the H2N2 A/Leningrad/134/57 ca virus. The studies were conducted in 1961-1964, years when some children would be expected to have hemagglutinin-specific antibody to the $\mathrm{H} 2 \mathrm{~N} 2$ virus, which caused the Asian influenza pandemic in 1957, and periodic epidemics thereafter until 1968. Immunization of these healthy children involved intranasal administration with a sprayer of two doses (at about a 2 week interval), each containing approximately $10^{7}$ EID $_{50}$ of the virus. Fever and clinical reactions were monitored for 5 days following immunization, and immunógenicity was evaluated by measuring the frequency of seroconversions detected by hemagglutinationinhibition (HI) tests. The percentage of children reported as showing febrile reactions (temperature $>38.5^{\circ} \mathrm{C}$ ) following this vaccination ranges from $0.1 \%$ to $0.8 \%$ with $92 \%$ 

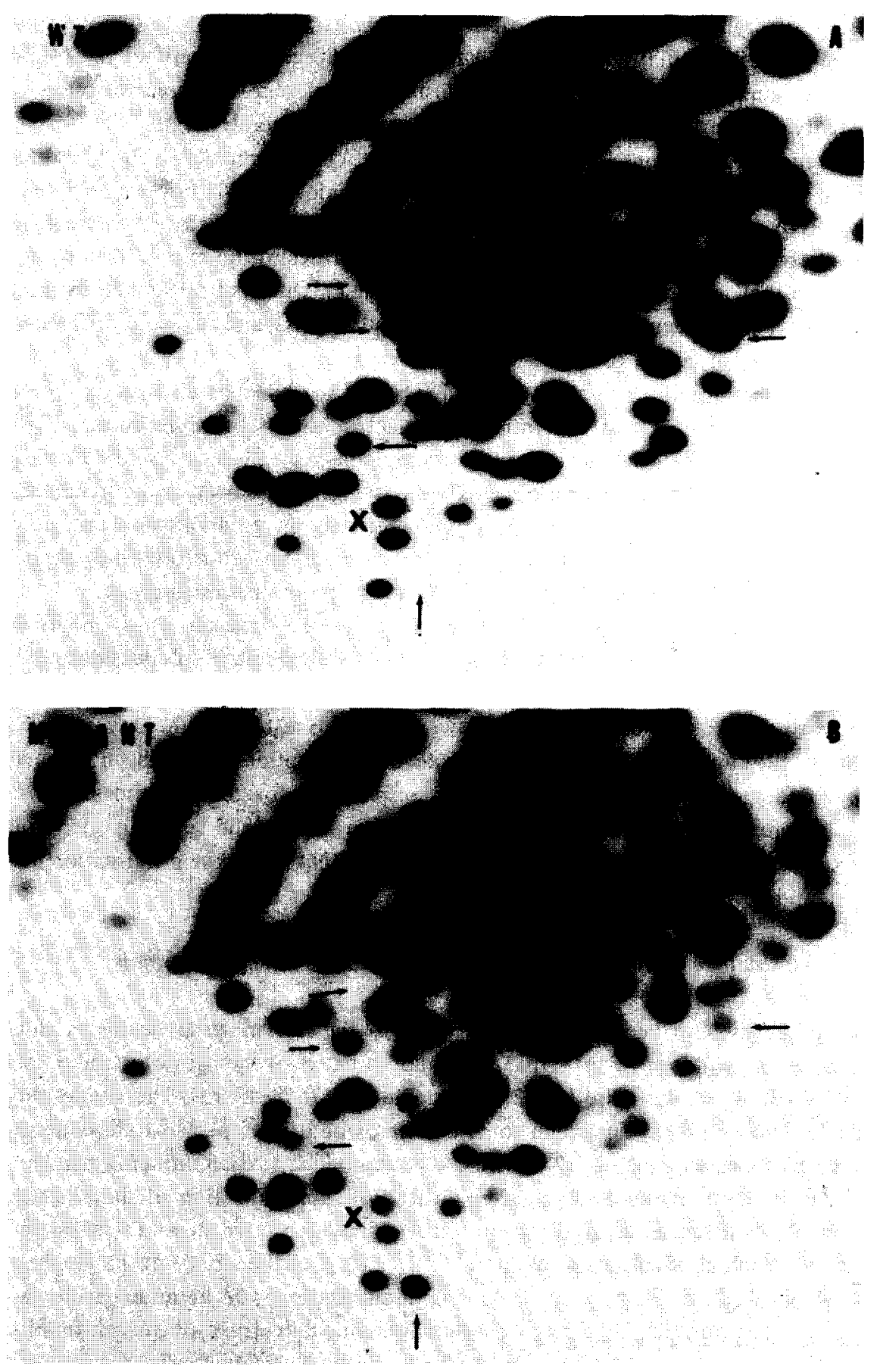

Fig. 1. Oligonucleotide map of virion RNA of $w t$ and $c a$ A/Ann Arbor/6/60. Differences between the viruses are indicated by arrows. 
exhibiting a $\geqslant 4$-fold rise in titer of $\mathrm{HI}$ antibodies. The A/Leningrad/9/46 (H1N1) $c a$ virus was tested in 130 7-14 year old children in 1970, a time when the children would be expected to lack any immunity from prior infection because H1N1 viruses did not circulate between 1957 and 1977 . Febrile reactions to the vaccine were reported in $0.7 \%$ of the children and a seroconversion rate of approximately $70 \%$ was obtained.

In the United States, the ca A/Ann Arbor/6/60 (H2N2) virus has never been tested in fully susceptible volunteers. Two studies, however, were done with volunteers known to possess low to moderate levels of neutralizing antibody [13]. In the first study, $6.4 \times 10^{4} \mathrm{TCID}_{50}$ of virus was administered to volunteers with serum-neutralizing antibody titers of $>16$, and no evidence for infection was obtained. In the second study, eight volunteers with serum-neutralizing antibody titers of between 4 and 16 were inoculated with approximately $3 \times 10^{5} \mathrm{TCID}_{50}$, and no illnesses were reported; virus was not recovered in the 9 days followed vaccination, but an antibody response was measured in seven of eight subjects 2 weeks after inoculation.

\section{RECOMBINANT $c a$ ATTENUATED STRAINS}

\section{Method of preparation}

Cold-adapted recombinant viruses deriving genes from the Leningrad $c a$ strains have been obtained by infection of eggs with approximately $10^{6}-10^{7} \mathrm{EID}_{50}$ of a mixture containing one $c a$ virus and one $w t$ strain. After mixed infection the eggs are incubated at $32^{\circ} \mathrm{C}$ for $10 \mathrm{~h}$ and subsequently two or three selective passages are performed in the presence of antiserum specific for the $c a$ parent. These selective passages are done at either $25^{\circ} \mathrm{C}$ or $32^{\circ} \mathrm{C}$. Final cloning of recombinants is done by triple-plaque purification in chick embryo kidney cell culture or, as a rule, by terminal dilution in chick embryos incubated at a temperature of $32^{\circ} \mathrm{C}$. This procedure has reliably selected recombinants having surface antigens of the $w t$ viruses and $c a$ properties of the Leningrad mutant parent used in the recombination.

Recombinants of the A/Ann Arbor/6/60 virus have been obtained by mixed infection of $\mathrm{CK}$ cells at $25^{\circ} \mathrm{C}$ with approximately 5 p.f.u./cell of each of the two viruses. The infected cells are incubated at $25^{\circ} \mathrm{C}$ for several days until cy topathic effects are observed and the tissue culture fluid then used as a source of $c a$ recombinants. Such recombinants are selected by two sequential passages in $\mathrm{CK}$ cells at $25^{\circ} \mathrm{C}$ in the presence of antiserum to the A/Ann Arbor/6/60 virus followed by two or three plaque purifications in CK cells at $25^{\circ} \mathrm{C}$ in the absence of sera [33]. To increase the possibility of obtaining recombinants with different gene combinations, it is now customary to establish the mixed infection in 10 or 20 parallel CK cultures which are then maintained independently through all the steps of the selection and cloning procedures [12].

Both in the U.S.S.R. and in the U.S.A. an attempt to increase the reproducibility of the recombination procedure, and to provide a better background for analyzing the effect of recombination on the $w t$ virus, has been the cloning of the $w t$ virus prior to the 
initiation of recombination. This cloning is done by passage of the $w t$ virus at $38-40^{\circ} \mathrm{C}$ in either eggs (U.S.S.R.) or bovine kidney or CK cells (U.S.A.) in order to assure that the parental virus is not $t$. At least one plaque purification or terminal dilution passage in eggs is undertaken as part of this $w t$ virus cloning procedure.

\section{Biological properties of recombinant ca viruses}

The Leningrad $c a$ viruses have been recombined with $w t$ influenza A (H1N1) or (H3N2) strains on eight occasions, and $c a$ vaccine candidates recovered that have antigens of the contemporary $w t$ isolates (Table 6). A majority of the recombinants had a $t s$ phenotype similar to that of their Leningrad parent, but in a few instances reduction or loss of ts phenotype occurred.

In the U.S.A. $c a$ A/Ann Arbor/6/60 has been recombined on nine occasions with $w t$ influenza $A(H 3 N 2)$ strains and on four occasions with wt influenza A (H1N1) strains $[11,12]$ (also see Table 12). More than 40 of the ca recombinants have been analyzed and with a single exception retained a highly ts phenotype [12,26,33,36] (and unpublished results). The exception, CR 13 clone 0 which was not ts [36], may be improperly cloned as it contains extra RNA segments when analyzed by gel electrophoresis (unpublished observations).

A/Ann Arbor/6/60 recombinant clones intended for use in human volunteer studies are also evaluated in susceptible ferrets infected, as a rule, with $10^{7}-10^{8}$ EID $_{50}$ of virus (approximately 100-1000 median ferret infectious doses). Histopathological studies are consistent with a milder response by the ferrets to infection with $c a$ recombinant than with wt virus (Fig. 2). Other markers examined are the ability to replicate well only in the turbinates (but poorly in the lungs), to have low reactogenicity, and not to revert in $t s$ or $c a$ phenotypes $[14,28]$. When ferret inoculum is in the range of $10^{7.0}-10^{8.0}$ $\mathrm{EID}_{50}$ the viruses were, with rare exception, restricted to growth in turbinates, and genetically stable (Table 7). On a single occasion revertant virus was isolated from ferrets infected with CR18 clone 7. Ferrets infected with CR31 clone 3, however, have consistently had virus isolated from lungs, and this virus was not $t s$. The non-ts reisolate has been phenotypically stable on subsequent ferret passage, but does not cause disease in the animals, indicating that the $t s$ phenotype can alter independently of attenuation in this animal model. The relationship of genetic composition to biological properties of the $c a$ recombinants is discussed below.

\section{Infectiousness, reactogenicity and immunogenicity of cold-adapted recombinant viruses}

Standardized procedures for safety and immunogenicity (phase 1) tests of $c a$ rếcombinants derived from the A/Ann Arbor/6/60 mutant have been developed that are currently followed by different clinical investigators in the U.S.A. This is done to provide uniform data on clinical reactogenicity, as well as to provide specimens for laboratory testing of virus replication, genetic stability and humoral immune response (Table 8). 


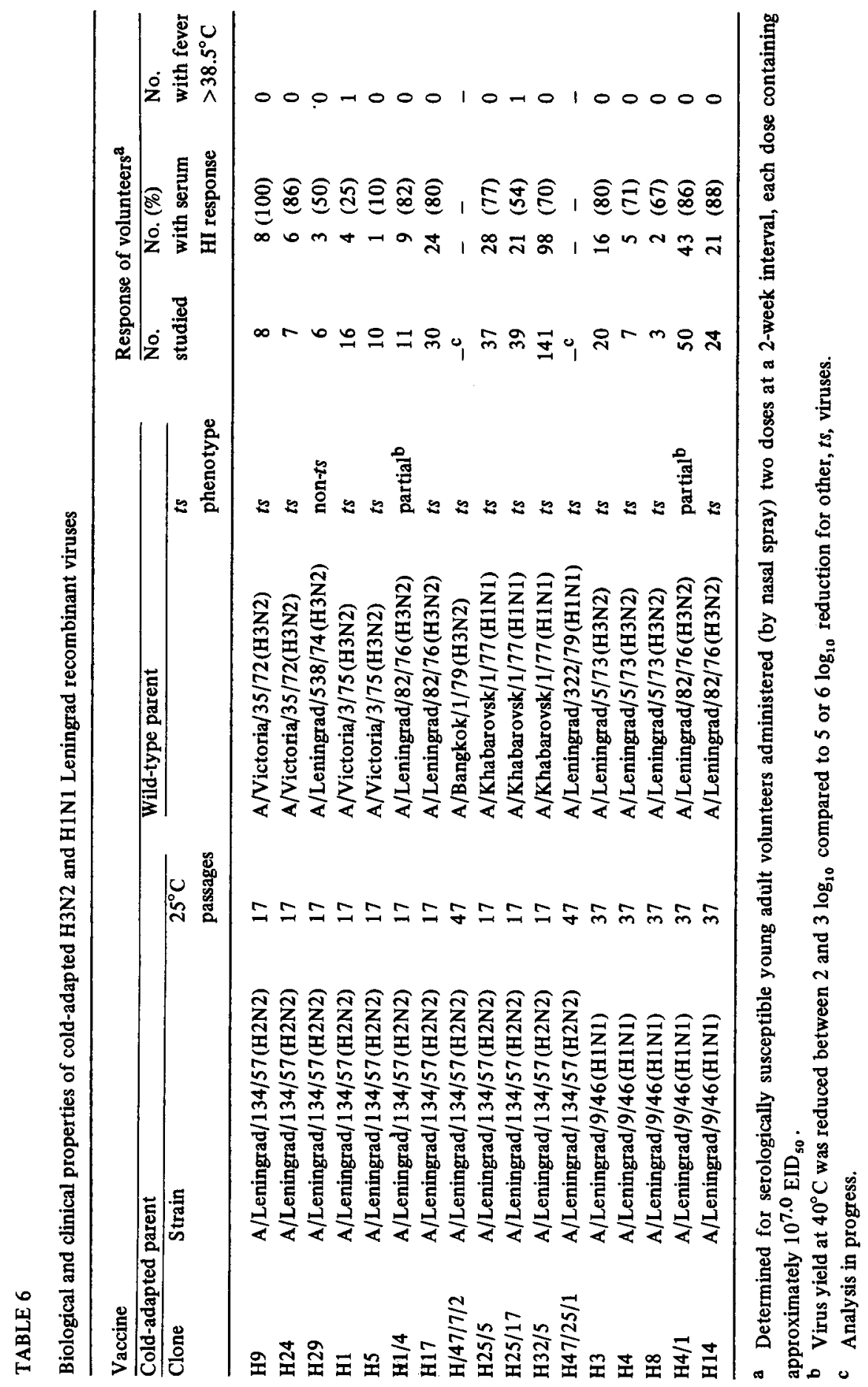



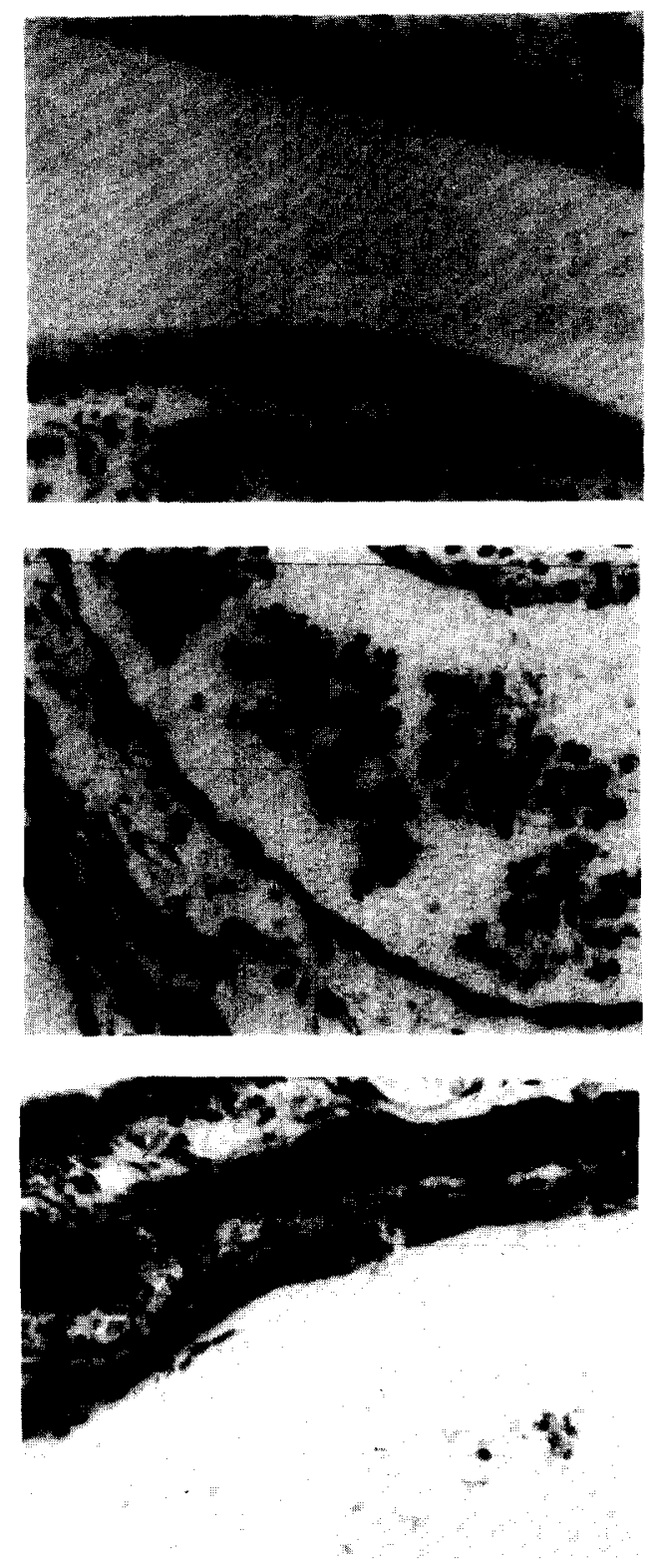

Fg. 2. Histopathology of nasal turbinates in ferrets infected with wild-type (wt) and cold-adapted (ca) recombinant influenza virus. A) Uninfected ferret. B) Ferret infected with $w t$ A/Victoria/3/75. At 4 days post-infection there is purulent rhinitis evidenced by the existence of an exudate of inflammatory cells, squamous metaplasia, and oedema of the connective tissue. C) Ferret infected with AA-CR19 clone 0 cold-adapted recombinant of A/Victoria/3/75. At 4 days post-infection localized rhinitis is observed with mild squamous metaplasia, but no purulent exudate. 
TABLE 7

Replication in ferrets of cold-adapted influenza viruses derived by recombination with cold-adapted A/Ann Arbor $/ 6 / 60^{\mathrm{a}}$

\begin{tabular}{|c|c|c|c|c|c|}
\hline \multirow[t]{2}{*}{ Recombinant } & \multirow[t]{2}{*}{$\begin{array}{l}\text { Infecting } \\
\text { dose }\end{array}$} & \multicolumn{2}{|c|}{$\begin{array}{l}\text { Duration of virus replication } \\
\text { (days) }\end{array}$} & \multirow[t]{2}{*}{ Reversion } & \multirow[t]{2}{*}{$\begin{array}{l}\text { Reacto- } \\
\text { genicity }\end{array}$} \\
\hline & & Turbinates & Lungs & & \\
\hline AA-CR 6 clone 0 & $7.5^{\mathrm{b}}$ & 3 & $<2^{c}$ & - & - \\
\hline AA-CR 18 clone 7 & 7.5 & 8 & $<2$ & $\begin{array}{l}\text { Non- } c a, \text { non-ts virus } \\
\text { at } 4 \text { days only }\end{array}$ & $-d$ \\
\hline AA-CR 19 clone 0 & 7.7 & 4 & $<2$ & - & _d \\
\hline AA-CR 22 clone 1 & 7.5 & 4 & $<2$ & - & - \\
\hline AA-CR 29 clone 2 & 7.7 & 5 & $<2$ & - & - \\
\hline AA-CR 31 clone 3 & 8.0 & 3 & 3 & $\begin{array}{l}\text { Stable non-ts virus } \\
\text { recovered in lungs }\end{array}$ & $-d$ \\
\hline AA-CR 31 clone 10 & 7.8 & 3 & $<2$ & - & - \\
\hline AA-CR 33 clone 1 & 7.5 & 3 & $<2$ & - & - \\
\hline AA-CR 35 clone 2 & 7.5 & 4 & $<2$ & - & - \\
\hline
\end{tabular}

a All wild-type parents of $c a$ viruses replicated in ferret lungs and produced fever associated with purulent rhinitis.

b $\log ^{10} \operatorname{EID}_{50}$.

c $<1 \log ^{10}$ EID $_{5 n}$ of virus present in $20 \%$ lung suspensions prepared from animals sacrificed $48 \mathrm{~h}$ post-infection.

d Short-lived low-grade fever and histopathological evidence of patchy or diffuse purulent rhinitis observed in some ferrets separately infected with $>10^{2 s} \mathrm{EID}_{\text {so }}$.

Expanded safety studies (phase 2) as well as studies of protective efficacy by artificial challenge or natural exposure in field trials (phase 3), are also undertaken. Additional studies have been described by investigators outside the U.S.A. for a few ca recombinants. A summary of clinical studies performed with the recombinants is given in Table 9.

Recombinants with $\mathrm{H} 3 \mathrm{~N} 2$ antigens, administered in phase 1 studies by nose drops at doses of $10^{6.5}-10^{7.5} \mathrm{TCID}_{50}$ or greater, have infected about $75-100 \%$ of vaccinees as judged by virus isolation and serum $\mathrm{HI}$ antibody response [14,25,40,42] (Table 10).

In these phase 1 trials usually no more than a single participant (about $10 \%$ of infected persons) has experienced more than a mild upper respiratory illness. Febrile or systemic symptoms in those few individuals who experienced them were transient and also not severe. In one trial, however, when undiluted AA-CR 18 virus containing $10^{8.5}$ TCID $_{50}$ of virus was administered, one-third of the volunteers experienced some febrile or systemic reactions [42]. Less pronounced symptoms resulted when a lower vaccine dose was used. Other evidence for possible dose response of reactions was the report that a high dose of AA-CR 22 vaccine was associated with transient afebrile systemic reactions [40], although these have not been seen with a smaller inoculum (R.B. Couch and T. Cates, unpublished results). These results with $\mathrm{H} 3 \mathrm{~N} 2$ ca recombinants of A/Ann 
TABLE 8

Protocol for phase 1 (safety) testing of live vaccine in healthy young adults in the U.S.A.

A. General procedure

1. Pre-bleed potential vaccine participants.

2. Test pre-study serum by HI, neutralization, or enzyme-linked immunosorbent (ELISA) assay, to identify volunteers who have maximum susceptibility to the vaccine virus.

3. Quarantine all selected volunteers in restricted access area for 2-3 days to monitor for any developing illness.

4. Under blind conditions, administer by drops vaccine or placebo $(0.5 \mathrm{ml} / \mathrm{nostril})$ to supine volunteers. Approximately $3 / 4$ of participants receive vaccine, the remainder placebo.

5. Monitor febrile, systemic and respiratory reactions and collect daily nasal wash specimens.

6. After 2 weeks collect final serum specimen. Volunteers depart from restricted access area.

B. Laboratory tests on specimens collected

1. Inoculation of tube cultures of monkey kidney (MK) or Madin-Darby canine kidney (MDCK) cells at the permissive temperature of $34^{\circ} \mathrm{C}$ with dilutions of nasal wash specimens to titrate post-inoculation replication of virus, and verify cessation of virus shedding. Additional virus isolation studies are undertaken to diagnose possible non-influenza infections in case of illness in participants.

2. Inoculation of tube cultures of MK or MDCK cells at the non-permissive temperature of $39^{\circ} \mathrm{C}$ with a low dilution of nasal wash specimens to detect possible revertant (non-ts) virus.

3. Titration of virus isolates in primary chicken kidney cells at $25^{\circ} \mathrm{C}, 33^{\circ} \mathrm{C}$ and $39^{\circ} \mathrm{C}$ to examine stability of $c a$ and $t s$ markers.

4. Titration of pre- and post-inoculation sera specimens by HI, and in some cases by neutralization and ELISA procedures, to detect and quantitate humoral antibody responses.

5. In some cases titration of nasal wash specimens by neutralization and ELISA procedures to quantitate local antibody responses.

Arbor/6/60 therefore suggest that, when given at doses of about $10^{7} \pm 0.5 \mathrm{TCID}_{50}$, the viruses are infectious and immunogenic for selected, serologically susceptible, young adult volunteers, but that undiluted vaccines containing $10^{8}$ or greater $\mathrm{TCID}_{50}$ may exhibit undesirable, albeit short-lived, reactions.

Open studies, in which participants are enrolled without prescreening of their serologic status, have been done for three H3N2 recombinants of $c a \mathrm{~A} / \mathrm{Ann}$ Arbor/6/60. Davenport and collaborators $[14,25]$ administered, by nasal spray rather than drops, $10^{6.5}$ $\mathrm{EID}_{50}$ of AA-CR6 to 25 healthy young adult volunteers, and compared doses of $10^{5.5}$, $10^{6.5}$ and $10^{7.5}$ EID $_{50}$ of AA-CR 19 administered by nasal spray to groups of approximately 40 young adults. No significant clinical reactions were observed in any study, although the majority of the participants possessed some pre-existing antibody that might have conferred protection against illness induced by the vaccine. In the study with $10^{6.5} \mathrm{EID}_{50}$ of AA-CR6 vaccine, $15 / 19(79 \%)$ of subjects with pre-existing $\mathrm{HI}$ antibody titers of $<64$ exhibited a 4 -fold antibody response. The study with AA-CR 19 demonstrated 4-fold or greater antibody responses in 10/28 (36\%), 15/26 (58\%) and 13/18 (72\%) of volunteers with pre-existing $\mathrm{HI}$ titer $<100$ following inoculation with $10^{5.5}$, 


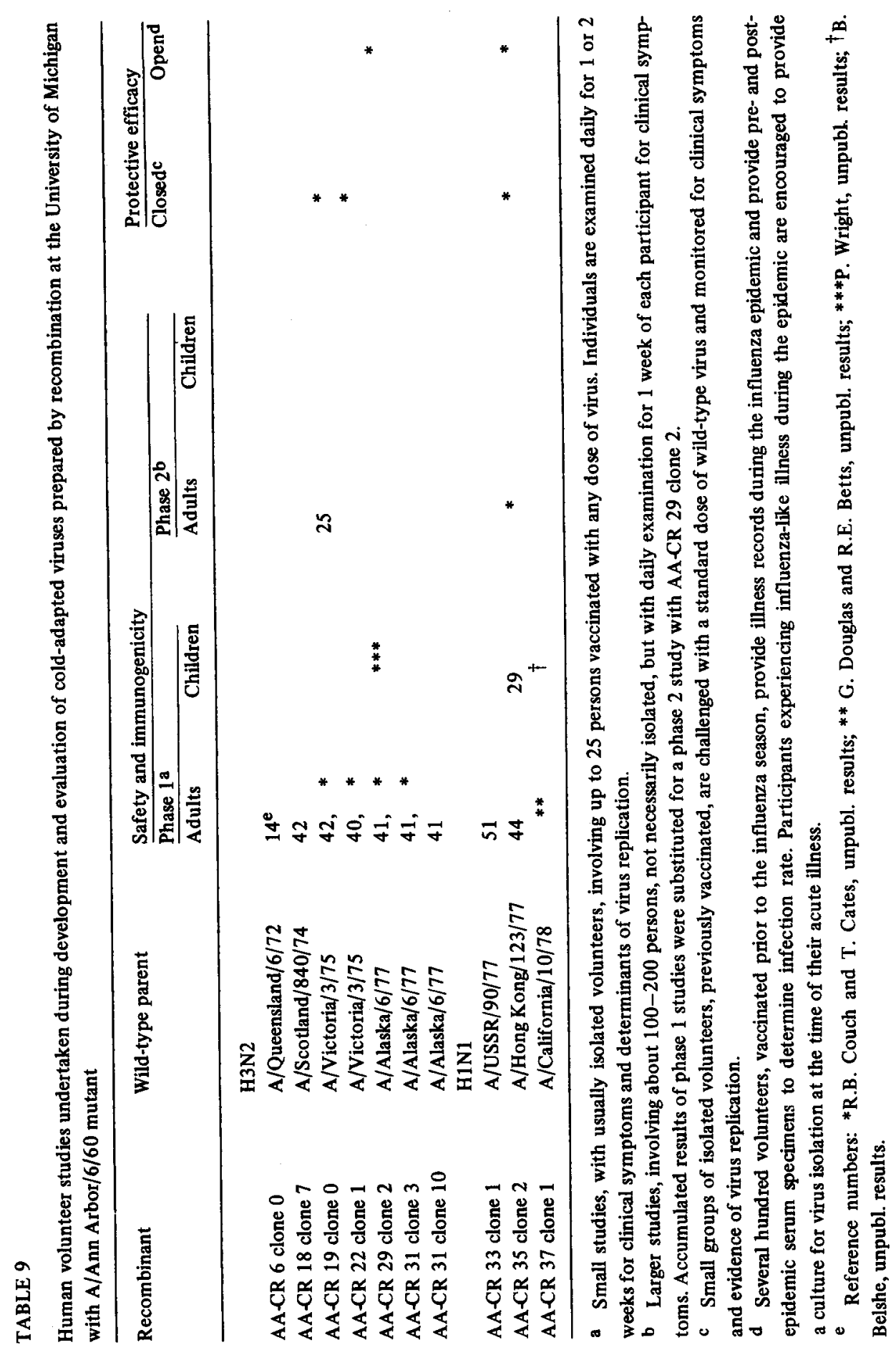




\section{TABLE 10}

Infectiousness, immunogenicity and reactogenicity of cold-adapted H3N2 A/Ann Arbor recombinant vaccines in phase 1 studies with young adult volunteers

\begin{tabular}{|c|c|c|c|c|c|c|}
\hline \multirow{2}{*}{$\begin{array}{l}\mathrm{H} 3 \mathrm{~N} 2 \\
\text { recombinants }\end{array}$} & \multirow{2}{*}{$\begin{array}{l}\text { Dose }\left(\log _{10}\right. \\
\left.\text { TCID }_{50}\right)\end{array}$} & \multirow{2}{*}{$\begin{array}{l}\text { No. of } \\
\text { volunteers }\end{array}$} & \multirow{2}{*}{$\begin{array}{l}\text { No. }(\%) \\
\text { infected }^{\mathrm{a}}\end{array}$} & \multicolumn{2}{|c|}{ No. (\%) infected with } & \multirow{2}{*}{$\begin{array}{l}\text { Refer- } \\
\text { ence }\end{array}$} \\
\hline & & & & $\begin{array}{l}\mathrm{HI} \\
\text { response }\end{array}$ & $\begin{array}{l}\text { Febrile or } \\
\text { systemic illness }\end{array}$ & \\
\hline \multirow{2}{*}{ CR 18 clone 7} & 7.5 & 10 & $8 \quad(80)$ & $6(75)$ & $1(13)$ & 50 \\
\hline & 8.5 & 12 & $12(100)$ & $11(92)$ & $4(33)$ & 50 \\
\hline \multirow[t]{2}{*}{ CR 19 clone 0} & 6.3 & 14 & $13(93)$ & $13(93)$ & $0(0)$ & 64 \\
\hline & 7.5 & 13 & $12(92)$ & $10(83)$ & $1(8)$ & 50 \\
\hline CR 22 clone 1 & 6.8 & 9 & $9(100)$ & $9(89)$ & $1(11)$ & 64 \\
\hline CR 29 clone 2 & 7.5 & 24 & $18(75)$ & $16(89)$ & $0(0)$ & 61 \\
\hline CR 31 clone 3 & 7.7 & 12 & $12(100)$ & $7(58)$ & $0(0)$ & 61 \\
\hline CR 31 clone 10 & 7.7 & 17 & $13(76)$ & $10(77)$ & $1(8)$ & 61 \\
\hline \multicolumn{7}{|l|}{$\begin{array}{l}\text { H1N1 } \\
\quad \text { recombinant }\end{array}$} \\
\hline CR 35 clone 2 & 7.5 & 25 & $24(96)$ & $11(46)^{b}$ & $0 \quad(0)$ & 53 \\
\hline
\end{tabular}

a Determined by virus isolation and antibody response.

b Increased to $100 \%$ by use of immunoassay to detect serum IgG and IgM antibody responses.

$10^{6.5}$ and $10^{7.5} \mathrm{EID}_{50}$ of virus, respectively. These results suggest that doses of about $10^{6.5}-10^{7.5} \mathrm{EID}_{50}$ of virus infect the majority of susceptible volunteers when given by spray. Studies are now planned to determine the median human infectious dose of cold-adapted A/Ann Arbor/6/60 recombinant vaccines in volunteers with low preexisting antibody, when vaccine is administered by nasal drops (B. Murphy, personal communication).

One open-field trial has been undertaken with AA-CR 29 clone 2 recombinant, in which groups of more than 200 college students received vaccine or placebo under blind conditions. No differences in respiratory illness rates reported by the students (21-29\%) were seen between the groups within the week following vaccination ( $R$. Couch and T. Cates, personal communication). Serologic responses and protection against natural infection are still under evaluation.

Cold-adapted H1N1 recombinants have also been evaluated in human volunteer tests. Phase 1 clinical studies using similar protocols to those developed with H3N2 candidate vaccines were undertaken in the U.S.A. with a $c a$ recombinant, AA-CR-35, which derives its $\mathrm{HA}$ and NA antigens from an A/USSR/90/77(H1N1)-like wt virus strain [44]. All of 24 selected serologically susceptible volunteers were infected when a virus dose of $10^{7.5} \mathrm{TCID}_{50}$ was administered (Table 10). Maximum detection of infection required the use of an enzyme immunoassay [46] to measure serum antibody responses, because only $45 \%$ of the participants responded to vaccination with a detectable serum HI antibody response. Similarly to the H3N2 ca recombinants, AA-CR 35 
did not cause significant clinical reactions when given at doses of $10^{7.5} \mathrm{TCID}_{50}$ or less. Comparable results were obtained with an additional recombinant (AA-CR33) of A/ USSR/90/77(H1N1)-like virus evaluated in Europe in young volunteers [51], and with a recombinant independently prepared in Europe from the A/Ann Arbor/6/60 ca parent $[51,61]$.

Clinical studies in the U.S.A. of the AA-CR35 H1N1 $c a$ recombinant in healthy young adults include a phase 2 study involving about 100 persons, and an open field trial in which about 700 college students were vaccinated. In these larger studies, no significant reactions were observed compared to the placebo groups, but the vaccine immunogenicity, as judged by conventional $\mathrm{HI}$ tests, was only about $50-60 \%$ in serologically susceptible vaccinees ( $R$. Couch and $T$. Cates, personal communication). This does not necessarily indicate low infectivity of the $c a$ recombinant, because natural infection similarly was associated with relatively poor antibody response in young adults during 1977 and 1978 , when measured with conventional HI tests [22].

Because of observations of low reactogenicity in young adults, AA-CR35 vaccine was considered safe for testing in small numbers of young children of 13-44 months old [29]. When a dose of $10^{6.5} \mathrm{TCID}_{50}$ was administered to 11 children, eight (73\%) were infected, all of these shedding virus (for up to 13 days) and demonstrating serum $\mathrm{HI}$ antibody response. No febrile or systemic reactions were observed (Dr. P. Wright, personal communication), and all virus isolates retained their $t s$ phenotype.

Attempts to demonstrate protective efficacy of the $c a$ recombinants have been undertaken by $R$. Couch and T. Cates (Personal communication), including the above-mentioned two open field trials, and studies where a small number of vaccinated volunteers are challenged with $w t$ virus under conditions similar to those used for the initial vaccination. To obtain maximum sensitivity in determining vaccine efficacy in the prevention of influenza illness, laboratory diagnosis of viral infection is undertaken to verify that any illnesses are caused by influenza virus, and placebo groups are included. A total of 25 volunteers vaccinated $1-3$ months previously with $c a \mathrm{H} 3 \mathrm{~N} 2$ or $\mathrm{H} 1 \mathrm{~N} 1$ recombinants have been challenged with wt virus without any evidence of illness, whereas 37 controls experienced 50-68\% illness rates (Table 11). Results of open field trials are still being evaluated.

Preliminary clinical evaluations in the U.S.S.R. of the $c a$ vinuses derived by recombination with the Leningrad $c a$ parental strains are done by immunizing healthy children or young adults, 17-25 years old, residents in communes. Pre-vaccine sera are collected and tested to identify vaccinees who have serum $H I$ antibody titers of $\leqslant 8$ to the vaccine strains. Some volunteers are also shown to lack detectable antineuraminidase antibody. The protocols are similar to those described above for evaluation of donor Leningrad ca strains.

Results indicate that in most instances greater than two-thirds of the serologically susceptible participants (i.e. whose pre-vaccine serum HI titer is $\leqslant 8$ ) were infected as judged by serum $\mathrm{HI}$ antibody response measurement (Table 6). Recombinants obtained with $\mathrm{A} /$ Victoria/3/75 wt virus, however, were poorly infectious and immunogenic, and 


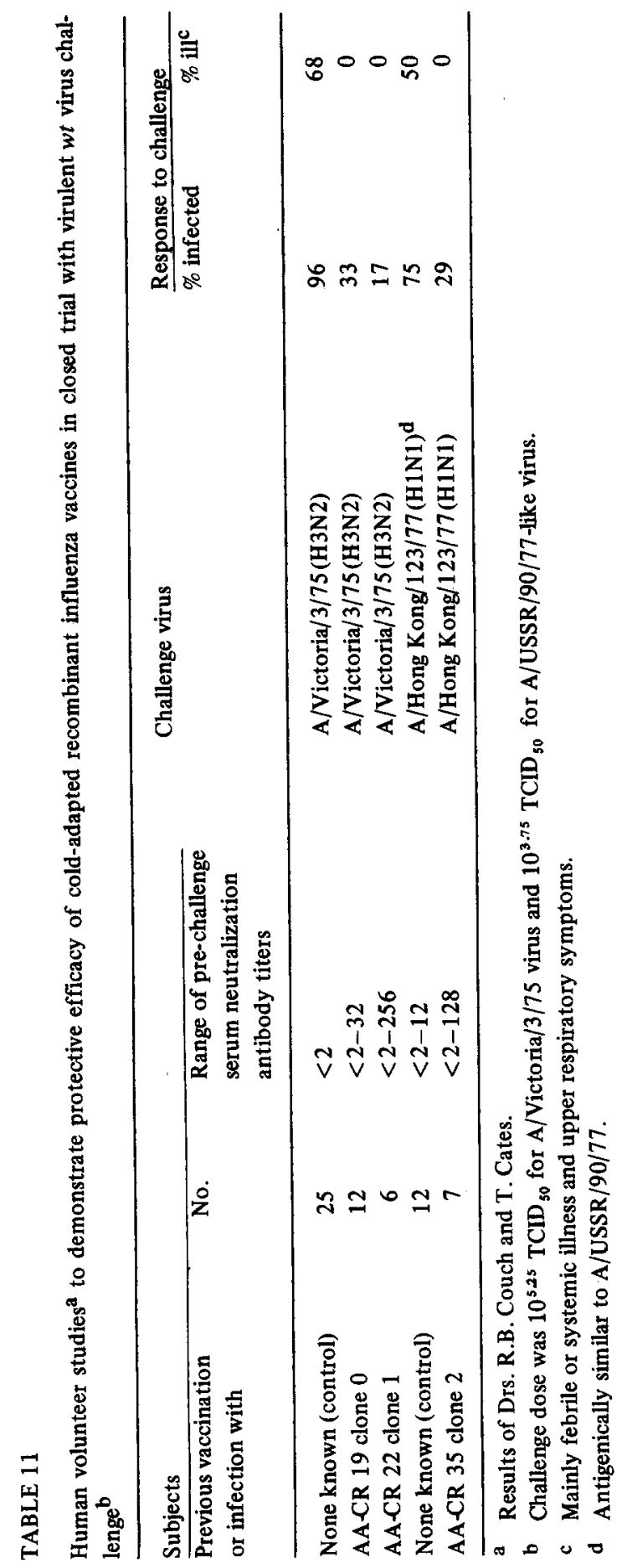


this may be attributable to the fact that the $w t \mathrm{~A} /$ Victoria/3/75 parent used in the recombination experiments in the Soviet Union had undergone a spontaneous mutation during laboratory passage, and in contrast to the A/Victoria/3/75 wt used in the U.S.A. had only moderate reactogenicity and immunogenicity [50]. The poor immunogenicity suggested by the results for the recombinant clone $\mathrm{H} 29$ derived from A/Leningrad/538/ 74 might be solely due to the small numbers tested.

For the H1N1 recombinant clones neuraminidase antibody responses following vaccination were also measured, to provide an additional indicator of immunogenicity. In initially seronegative participants, neuraminidase antibody response was detected for $37 \%, 24 \%$ and $15 \%$, respectively, with clones $\mathrm{H} 32 / 5, \mathrm{H} 25 / 17$ and $\mathrm{H} 25 / 5$. All of the tested vaccines were highly attenuated, and clone $\mathrm{H} 32 / 5$ which had the highest overall immunogenicity was therefore selected for use in vaccine manufacture.

Clones $H 47 / 7 / 2$ and $H 47 / 25 / 1$ which were attenuated by recombination between $\mathrm{A} /$ Bangkok/1/79(H3N2) or $\mathrm{A} /$ Leningrad/322/79(H1N1) $w t$ strains respectively and the 47-times, $25^{\circ} \mathrm{C}$-passaged A/Leningrad/134/57(H2N2) ca mutant are presently being evaluated in 7-14 year old children, with preliminary results indicating a reactogenicity and high immunogenicity (M.R. Zykov, personal communication).

Studies of protective efficacy by the $c a$ Leningrad recombinants are not done by means of artificial challenge of volunteers immunized with vaccine or placebo, but by monitoring reported illness rates among vaccinated and non-vaccinated groups during the winter season. Under these circumstances, when laboratory diagnosis of infection is not done, vaccine efficacy in reducing acute respiratory disease is dependent on the proportion of influenza to non-influenza infections in the communities studied (Uy.G. Ivannikov, personal communication).

\section{Effect of genome composition on properties of ca recombinant live-vaccine candidates}

Genome analyses of $c a$ viruses derived by recombination with $c a$ A/Ann Arbor/6/60 at $25^{\circ} \mathrm{C}$ have revealed them to have a highly restricted composition. Of 40 clones examined, $24(61 \%)$ possessed only the HA and NA of $w t$ virus, but all other genes from the $c a$ A/Ann Arbor/6/60 parent (Table 12) [11,12]. The remaining viruses always contained P2, P3 and nucleoprotein genes from the Ann Arbor ca parent, but a single one of the P1, matrix protein or non-structural protein genes from the $w t$ parent. Several recombinants with $w t$ P1 or non-structural proteins were recovered, but have not been found to differ markedly in any biological property from recombinants with all non-HA- and non-NA genes derived from the $c a$ A/Ann Arbor/6/60 parent (Table 7) $[12,26,27]$. However, relative temperature sensitivity of $A / A n n$ Arbor/6/60 recombinants can apparently vary somewhat, independently of gene combinations [43] .

Only a single recombinant derived at $25^{\circ} \mathrm{C}$ was determined to have a wt matrix protein. As described above (Table 7), this recombinant (AA-CR 31 clone 3) exhibited instability of its $t s$ phenotype in ferrets, supporting the view from results with recombinants derived at temperatures other than $25^{\circ} \mathrm{C}$ that matrix protein was involved in the 
TABLE 12

Gene composition of cold-adapted Ann Arbor viruses derived by recombination at $25^{\circ} \mathrm{C}$

\begin{tabular}{|c|c|c|c|c|c|c|c|c|c|c|}
\hline \multicolumn{3}{|c|}{ Recombinants } & \multirow{2}{*}{ HA } & \multirow{2}{*}{ NA } & \multicolumn{6}{|c|}{ Derivation of genes ${ }^{a}$} \\
\hline$\overline{\text { Expt. }}$ & Wild-type parent & Clone & & & $\begin{array}{l}\overline{\mathrm{P} 3} \\
\text { (RNA 1) }^{\mathrm{B}}\end{array}$ & $\begin{array}{l}\text { P1 } \\
\text { (RNA 2) }^{b}\end{array}$ & $\begin{array}{l}\text { P2 } \\
\text { (RNA 3) }^{b}\end{array}$ & $\mathbf{N P}$ & $\mathrm{M}$ & $\mathbf{N S}$ \\
\hline AACR 6 & A/Queensland/6/72(H3N2) & 0 & $\mathbf{w}$ & $w$ & A & $\mathbf{A}$ & $\mathbf{A}$ & $\mathbf{A}$ & $\mathbf{A}$ & A \\
\hline AACR 12 & A/Ann Arbor/9/73(H3N2) & $\mathbf{0}$ & w & w & $\mathbf{A}$ & $\mathbf{A}$ & $\mathbf{A}$ & A & $\mathbf{A}$ & $\mathbf{A}$ \\
\hline \multirow[t]{2}{*}{ AACR 13} & A/Dunedin/4/73(H3N2) & 5 & $\mathbf{w}$ & $w$ & A & w & $\mathbf{A}$ & A & $\mathbf{A}$ & $\mathbf{A}$ \\
\hline & & 9 & w & w & $\mathbf{A}$ & w & A & $\mathbf{A}$ & $\mathbf{A}$ & A \\
\hline \multirow[t]{5}{*}{ AACR 18} & A/Scotland $/ 840 / 74(\mathrm{H} 3 \mathrm{~N} 2)$ & 0 & w & w & $A$ & $\mathbf{A}$ & $\mathbf{A}$ & $\mathbf{A}$ & $\mathbf{A}$ & $w$ \\
\hline & & 4 & w & $\mathbf{A}$ & $\mathbf{A}$ & A & $\mathbf{A}$ & $\mathbf{A}$ & $\mathbf{A}$ & $\mathbf{w}$ \\
\hline & & 5 & w & $\mathbf{A}$ & $\mathbf{A}$ & $\mathbf{A}$ & $A$ & A & $\mathbf{A}$ & $\mathbf{w}$ \\
\hline & & 6 & w & w & $\mathbf{A}$ & $\mathbf{A}$ & $\mathbf{A}$ & $\mathbf{A}$ & $\mathbf{A}$ & $\mathbf{w}$ \\
\hline & & 7 & $w$ & w & A & $\mathbf{A}$ & A & A & $\mathbf{A}$ & $\mathbf{w}$ \\
\hline AA-CR 19 & A/Victoria/3/75(H3N2) & 0 & $w$ & $\mathbf{w}$ & A & w & $\mathbf{A}$ & $\mathbf{A}$ & $\mathbf{A}$ & $\mathbf{A}$ \\
\hline \multirow[t]{2}{*}{ AA-CR 22} & A/Victoria/3/75(H3N2) & 1 & $w$ & w & A & w & $\mathbf{A}$ & $\mathbf{A}$ & $\mathbf{A}$ & A \\
\hline & & 17 & w & $A$ & $\mathbf{A}$ & A & $\mathbf{A}$ & A & $\mathbf{A}$ & A \\
\hline \multirow[t]{2}{*}{ AACR 29} & A/Alaska/6/77(H3N2) & 2 & w & w & $\mathbf{A}$ & $\mathbf{A}$ & $\mathbf{A}$ & $\mathbf{A}$ & $\mathbf{A}$ & A \\
\hline & & 17 & $w$ & w & $\mathbf{A}$ & A & $\mathbf{A}$ & $\mathbf{A}$ & $\mathbf{A}$ & A \\
\hline \multirow[t]{10}{*}{ AACR 31} & A/Alaska/6/77(H3N2)c & 2 & $w$ & $W$ & A & A & A & A & $A$ & $A$ \\
\hline & & 3 & $w$ & $w$ & A & $\mathbf{A}$ & A & A & w & A \\
\hline & & 4 & w & A & $\mathbf{A}$ & $\mathbf{A}$ & A & A & $\mathbf{A}$ & A \\
\hline & & 10 & w & $w$ & A & A & $\mathbf{A}$ & A & $\mathbf{A}$ & $w$ \\
\hline & & 12 & $w$ & $w$ & A & $\mathbf{A}$ & A & A & $\mathbf{A}$ & $w$ \\
\hline & & 13 & $w$ & $w$ & $\mathbf{A}$ & $\mathbf{A}$ & $\mathbf{A}$ & $\mathbf{A}$ & $\mathbf{A}$ & A \\
\hline & & 16 & $w$ & A & A & $\mathbf{A}$ & A & A & $\mathbf{A}$ & A \\
\hline & & 17 & W & A & $\mathbf{A}$ & $\mathbf{A}$ & $\mathbf{A}$ & A & $\mathbf{A}$ & A \\
\hline & & 19 & $w$ & W & $\mathbf{A}$ & $\mathbf{A}$ & $A$ & A & $\mathbf{A}$ & A \\
\hline & & 20 & w & w & $\mathbf{A}$ & $\mathbf{A}$ & A & A & $\mathbf{A}$ & A \\
\hline \multirow[t]{2}{*}{ AACR 33} & (A/USSR/90/77(H1N1) & 1 & w & w & A & $\mathbf{A}$ & A & A & $\mathbf{A}$ & $\mathbf{A}$ \\
\hline & & 2 & w & $\mathbf{w}$ & A & A & $\mathbf{A}$ & A & $\mathbf{A}$ & $A$ \\
\hline AA-CR 35 & A/Hong Kong/ $123 / 77(\mathrm{H} 1 \mathrm{~N} 1)^{\mathrm{c}}$ & 2 & w & w & $\mathbf{A}$ & $A$ & A & A & $\mathbf{A}$ & A \\
\hline \multirow[t]{8}{*}{ AACR 36} & A/Hong Kong/ $123 / 77(\mathrm{H} 1 \mathrm{~N} 1)^{\mathrm{c}}$ & 1 & w & $\mathbf{w}$ & A & $\mathbf{A}$ & $\mathbf{A}$ & A & $\mathbf{A}$ & A \\
\hline & & 2 & w & w & $\mathbf{A}$ & $\mathbf{A}$ & A & $\mathbf{A}$ & $\mathbf{A}$ & A \\
\hline & & 3 & w & w & $\mathbf{A}$ & $\mathrm{A}$ & A & $\mathrm{A}$ & $\mathbf{A}$ & $\mathbf{A}$ \\
\hline & & 4 & W & $\mathbf{A}$ & $\mathbf{A}$ & $\mathbf{A}$ & A & $\mathbf{A}$ & $\mathbf{A}$ & $\mathbf{A}$ \\
\hline & & 5 & w & w & A & $\mathbf{A}$ & $\mathbf{A}$ & A & $\mathbf{A}$ & A \\
\hline & & 7 & $w$ & w & $\mathbf{A}$ & $\mathbf{A}$ & A & A & $\mathbf{A}$ & A \\
\hline & & 9 & w & $w$ & $\mathbf{A}$ & $\mathbf{A}$ & $\mathbf{A}$ & A & $\mathbf{A}$ & A \\
\hline & & 10 & w & w & $\mathbf{A}$ & $\mathbf{A}$ & $\mathbf{A}$ & A & $\mathbf{A}$ & $\mathbf{A}$ \\
\hline AACR 37 & A/California/10/78(H1N $)$ & 1 & w & $w$ & $\mathbf{A}$ & $\mathbf{A}$ & $\mathbf{A}$ & $\mathbf{A}$ & $\mathbf{A}$ & $\mathbf{A}$ \\
\hline \multirow[t]{4}{*}{$A A C R 44$} & A/Beijing/2/79(H3N2) ${ }^{c}$ & 6 & w & W & $\mathbf{A}$ & $\mathbf{A}$ & A & A & $\mathbf{A}$ & A \\
\hline & & 11 & $\mathbf{w}$ & $w$ & $\mathbf{A}$ & $\mathbf{A}$ & $\mathbf{A}$ & A & $\mathbf{A}$ & $w$ \\
\hline & & 16 & w & $\mathbf{W}$ & $\mathbf{A}$ & $\mathbf{A}$ & $\mathbf{A}$ & $\mathbf{A}$ & $\mathbf{A}$ & $\mathbf{A}$ \\
\hline & & 20 & $\mathbf{A}$ & $w$ & $\mathbf{A}$ & A & $\mathbf{A}$ & A & $\mathbf{A}$ & $\mathbf{A}$ \\
\hline
\end{tabular}

a W indicates gene derived from wild-type parent. A indicates gene derived from mutant parent.

b For reference conditions of electrophoresis without urea at $38^{\circ} \mathrm{C}[26]$.

c Adapted to growth in primary bovine kidney cells and cloned at $39^{\circ} \mathrm{C}$ in these cells.

expression of the A/Ann Arbor/6/60 ts phenotype. AA-CR 31 clone 3 did not exhibit unusual properties in a human volunteer study, however, and non-ts revertants were not detected amongst isolates recovered from the vaccinees [41]. 
Occasionally viruses exhibiting partial reversion in either the $t s$ or the ca phenotype (but not both phenotypic markers) have been identified as a small proportion of virus isolated from human volunteers or hamsters infected with Ann Arbor ca recombinants $[42,55]$. There has not yet been an examination of genetic changes or changes in human virulence, that might be exhibited by such partial revertants.

The two $c a$ recombinants used in the U.S.S.R. as live vaccines in public immunization programs in recent years, i.e. the $\mathrm{H} 17$ clone of $\mathrm{A} /$ Leningrad/82/76(H3N2), and the 32/5 clone of $\mathrm{A} / \mathrm{Khabarovsk} / 1 / 77(\mathrm{H} 1 \mathrm{~N} 1)$, both contain only the $\mathrm{HA}$ and NA of their respective $w t$ parent, but all six other genes derived from the A/Leningrad/134/57 (H2N2) ca parent [17] (Table 13). Recombinant clones $H 47 / 7 / 2$ and $H 47 / 25 / 1$ which were recently prepared using the 47 -times, $25^{\circ} \mathrm{C}$-passaged A/Leningrad/134/57(H2N2) parent similarly derived only their HA and NA genes from their $w t$ parents. Two other recombinants, $H / 1 / 4$ and $H / 4 / 1$ contained at least all seven genes other than the $M$ protein from that $w t$ parent and were non-ts or partially $t s$ respectively. The matrix protein gene in recombinant $\mathrm{H} / 1 / 4$ could not be identified by the procedure used as it appeared to have undergone a spontaneous mutation during recombination and was not identical to the matrix protein in either parent. Results of genome analysis suggest that the matrix protein is probably not required for the ca phenotype of either A/Leningrad/134/57 or A/Leningrad/9/46 ca donors, but is involved in the ts phenotype of these viruses. Comparison of genotype with results of clinical testing [17] (Tables 6 and 13) suggests that even those recombinants possessing only a single gene (M) from the $c a$ parent were attenuated. Evaluation of genetic stability of recombinants during replication in human volunteer studies has been done for the H17 clone which contains all non-HA, non-NA genes from its $c a$ parent. Eight isolates were obtained from vaccinees shedding virus and all retained the $t s$ phenotype, although the difference in titers at $40^{\circ} \mathrm{C}$ and $32^{\circ} \mathrm{C}$ for the isolates was $1-2 \log _{10}$ less than in the original vaccine.

\section{SUMMARY AND CONCLUSIONS}

In the Soviet Union and the United States $c a$ variants of influenza A virus have been selected by multiple passage at temperatures suboptimal for replication of $w t$ virus. These ca variants replicate efficiently at $25^{\circ} \mathrm{C}$ or $28^{\circ} \mathrm{C}$ but are highly temperature-sensitive and unlike many $w t$ influenza $\mathrm{A}$ viruses will not replicate at $39-40^{\circ} \mathrm{C}$.

The ca mutant most widely used for preparing experimental vaccine strains in the U.S.A. is Ann Arbor/6/60 (H2N2), but due to a lack of serologically susceptible adult volunteers this variant has itself been only partially characterized for clinical and immunological response in man. However, a series of recombinants deriving five or six of the non-HA, non-NA genes from the A/Ann Arbor/6/60 mutant, but HA, NA and sometimes one other, genes from $w t \mathrm{H} 3 \mathrm{~N} 2$ or $\mathrm{H} 1 \mathrm{~N} 1$ strains have been tested in serologically susceptible human volunteers. When given by nose drop or spray at doses of about $10^{7} \mathrm{TCID}_{50}$ or $\mathrm{EID}_{\text {so }}$ the viruses are highly attenuated. $\mathrm{H} 3 \mathrm{~N} 2$ recombinants are highly immunogenic, but $\mathrm{H} 1 \mathrm{~N} 1$ recombinants which are also attenuated have often appeared less immunogenic 


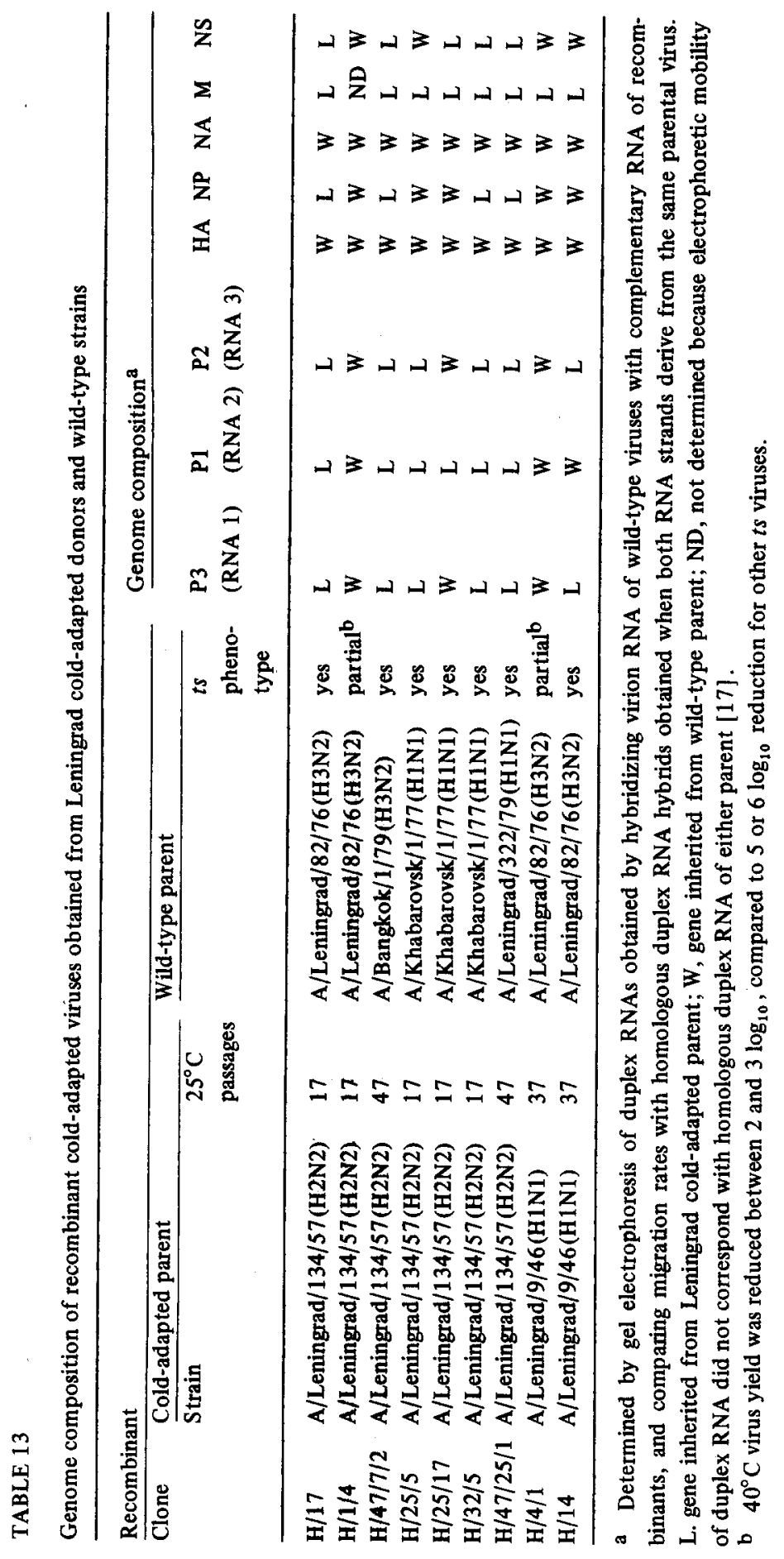


when traditional assays for antibody response are used. Preliminary studies of protective efficacy using artificial challenges have been undertaken with encouraging results in small numbers of volunteers.

Genetic and biochemical analysis has identified the existence of mutations in all eight genes of the $c a$ A/Ann Arbor/6/60 virus, and those coding for the polymeraseassociated proteins $\mathrm{P} 1, \mathrm{P} 2$ and $\mathrm{P} 3$, as well as the matrix protein have been implicated in some way with genetic or phenotypic in vitro markers, although the relevance to attenuation of any mutation detected by these means is unclear. Occasional partial revertants in $c a$ or $t s$ phenotype have been shed by persons or animais infected with Ann Arbor-ca recombinants. Further studies are necessary to determine whether reversion of $c a$ or $t s$ phenotypes is associated with increased virulence. Production of reproducible ca recombinants has probably been facilitated by their ability to produce plaques at $25^{\circ} \mathrm{C}$ which provides a positive selection mechanism. Techniques used consistently identify with high frequency recombinants possessing all non-HA, non-NA genes from their $c a$ A/Ann Arbor/6/60 parent.

In the U.S.S.R. many findings are analogous to those in the U.S.A. The ca mutant most widely used for preparing vaccine strains, A/Leningrad/134/57, is also an $\mathrm{H} 2 \mathrm{~N} 2$ virus similar to A/Ann Arbor/6/60, although another $c a$ parent, A/Leningrad/9/46(H1N1), is sometimes used. Both viruses have been tested for their infectiousness, immunogenicity and reactogenicity by administration of $10^{7}$ infectious units with a nasal spray to young children, and were reported to be attenuated and immunogenic. A series of recombinants prepared with these $c a$ parents and diverse $w t$ parents usually shared the important biological properties of the $c a$ parent, and the recombinants with properties most suitable for vaccine use possess all non-HA, non-NA genes of their $c a$ parent.

Genetic analysis indicates the existence of mutations in several genes of the Leningrad ca parents and implicates the matrix protein as containing a mutation necessary for temperature sensitivity. Revertant viruses have not yet been identified as being shed by vaccinated persons in the small number of instances this has been evaluated. Studies of protective efficacy by artificial challenge of vaccinated volunteers with virulent $w t$ virus are not possible in the Soviet Union, and analysis of vaccine efficacy is dependent on epidemiological observations of large population groups during periods of natural virus circulation.

The common viewpoint is held by the authors that the identification of multiple mutations in $c a$ parent strains following their selection in the laboratory, and the ability to transfer most or all of these genes to contemporary wt strains by recombination (reassortment), facilitates the regular production of $c a$ recombinants with reproducible biological properties and minimal chances of reverting to virulence, even though the actual genetic basis for attenuation is unknown, in common with other live virus vaccines. A possible effect of HA and NA genes from the $w t$ parent or the recombinants is not totally excluded, however. Studies of the relative efficacy of live attenuated vaccines, compared to inactivated vaccines, in populations with different immunological backgrounds and when exposed to different $w t$ virus strains have yet to be done. Continued 
development, evaluation, and comparison of live and inactivated influenza vaccines must continue as one approach to improving influenza prophylaxis, and at the present time ca influenza viruses are highly useful in preparing live vaccines for this purpose.

\section{ACKNOWLEDGEMENTS}

The authors gratefully acknowledge the collaboration of Drs. F. Palezhaev, A. Klimov, K. Lisouskaya, T. Medvedeva, L. Garmahoua in the U.S.S.R., and Drs. G. Abrams, A. Betts, T. Cates, R. Chanock, R. Couch, N. Cox, G. Douglas, I. Konnecke, A. Monto, B. Murphy, S. Spring and P. Wright in the U.S.A. for their collaboration in studies of cold-adapted influenza virus and for making available their unpublished results. Investigations by A.P.K. and H.F.M. are supported by agreement Y01 AI-80001 and contract I-AI72521 with the National Institute of Allergy and Infectious Diseases, NIH.

\section{REFERENCES}

1 Alexandrova, G.I. (1971) Basic trends in vaccination of children against influenza by use of live vaccine. In: Proc. Symp, on Live Influenza Vaccines (Yugoslav Acad. Sci. Arts, Zagreb) pp. 121 130.

2 Alexandrova, G.I. (1977) The use of genetic recombination in preparing of influenza vaccine strains. Vopr. Virusol. 4, 179-186.

3 Alexandrova, G.I., Garmashova, L.M., Golubev, D.B., Koljak, L.I., Medvedeva, T.E. and Polezhaev, F.I. (1979) The experience of selection of thermosensitive recombinants of influenza virus type A. Vopr. Virusol. 4, 342-346.

4 Alexandrova, G.I. and Smorodintsev, A.A. (1965) Obtaining of an additionally attenuated vaccinating cryophilic influenza strain. Rev. roum. Intramicrobiol. 2, 179-186.

5 Alling, D.W., Blackwelder, W.C. and Stuart-Harris, C.H. (1981) A study of excess mortality during influenza epidemics in the United States, 1968-1976. Am. J. Epidemiol. 113, 30-43.

6 Almond, Y., MoGeoch, D. and Barry, R. (1979) Temperature-sensitive mutants of fowl plague virus: isolation and genetic characterisation. Virology 92, 416-427.

7 Barker, W.H. and Mullooly, J.P. (1980) Impact of epidemic type A influenza in a defined adult population. Am. J. Epidemiol. 112, 798-813.

8 Beare, A.S. and Hall, T.S. (1971) Recombinant influenza-A viruses as live vaccines for man. Lancet 2, 1271-1273.

9 Beare, A.S., Maassab, H.F., Tyrrell, D.A.J., Slepushkin, A.N. and Hall, T.S. (1971) A comparative study of attenuated influenza viruses. Bull. W.H.O. 44, 593-598.

10 Beare, A.S., Schild, G.C. and Craig, J.W. (1975) Trials in man with live recombinants made from $\mathrm{A} / \mathrm{PR} / 8 / 34(\mathrm{HON} 1)$ and wild $\mathrm{H} 3 \mathrm{~N} 2$ influenza viruses. Lancet 2, 729-732.

11 Cox, N.J., Konnecke, I., Kendal, A.P. and Maassab, H.F. (1981) Genetic and biochemical analysis of the A/Ann Arbor/6/60 cold adapted mutant. In: ICN-UCLA Symposium on Recent Advances in Genetics of Influenza Virus, eds. D. Nayak and C.F. Fox (Academic Press, New York) (in press).

12 Cox, N.J., Maassab, H.F. and Kendal, A.P. (1979) Comparative studies of wild-type and coldmutant (temperature-sensitive) influenza viruses: nonrandom reassortment of genes during preparation of live virus vaccine candidates by recombination at $25^{\circ} \mathrm{C}$ between recent $\mathrm{H} 3 \mathrm{~N} 2$ and H1N1 epidemic strains and cold-adapted A/Ann Arbor/6/60. Virology 97, 190-194.

13 Cox, N.J., Kendal, A.P., Maassab, H.F., Scholtissek, C. and Spring, S.B. (1981) Genetic synergism 
between matrix protein and polymerase protein required for temperature sensitivity of the coldadapted influenza A/Ann Arbor/6/60 mutant virus. In: Replication of Negative Strand Viruses, eds. D.H.L. Bishop and R. Compans (Elsevier/North-Holland, Amsterdam) pp. 405-413.

14 Davenport, F.M., Hennessy, A.V., Maassab, H.F., Minuse, E., Clark, L., Abrams, G.D. and Mitchell, J.R. (1977) Pilot studies on recombinant cold-adapted live type $A$ and $B$ influenza virus vaccines. J. Infect. Dis. 136, 17-25.

15 Davies, J.R., Smith, A.J., Miller, C.L. and Allchin, A. (1979) Assessment of inactivated influenza$A$ vaccines after three outbreaks of influenza $A$ at Christ's Hospital. Lancet 1, 33- 35 .

16 Florent, G., Lobmann, M., Beare, A.S. and Zygraich, N. (1977) RNAs of influenza virus recombinants derived from parents of known virulence for man. Arch. Virol. 54, 19-28.

17 Ghendon, Y.Z., Klimov, A.I., Alexandrova, G.I. and Polezhaev. F.I. (1981) Analysis of genome composition and reactogenicity of recombinants of cold-adapted and virulent virus strains. $J$. Gen. Virol. 53, 215-224.

18 Ghendon, Y. and Markushin, S. (1980) Studies on mutations, lesions and physiology of fowl plague virus ts mutants. Philos. Trans. R. Soc. B288, 383-292.

19 Ghendon, Y.Z., Markushin, S.G., Blogoveshenskaya, O.V. and Ghenkina, D.B. (1975) Study of fowl plague virus RNA synthesis in temperature-sensitive mutants. Virology 66, 454-463.

20 Ghendon, Y.Z., Markushin, S.G., Marchenko, A.T., Sitnikov, B.S. and Ginzburg, V.P. (1973) Biochemical characteristics of fowl plague virus $t s$ mutants. Virology 55, 305-319.

21 Glezen, P.W. and Couch, R.B. (1974) Interpandemic influenza in the Houston area, 1974-76. N. Engl. J. Med. 298, 587-592.

22 Hammond, G.W., Smith, S.J. and Noble, G.R. (1980) Sensitivity and specificity of enzyme immunoassay for serodiagnosis of influenza A virus infections. J. Infect. Dis. 141, 644-651.

23 Hay, A.J., Skehel, J.J. and Webster, R.G. (1979) Differentiation of the haemagglutinin genes of variant influenza viruses by RNA-RNA hybridization. J. Gen. Virol. 45, 245- 248.

24 Ghenkina, D.B. and Ghendon, Y.Z. (1973) Recombination and complementation of orthomyxoviruses in the conditions of abortive infection. Acta Virol. 23, 97-106.

25 Hrabar, A., Vodopija, I., Andre, F.E., Mitchell, J.R., Maassab, H.F., Hennessy, A.V. and Davenport, F.M. (1977) A placebo-controlled dose-response study of the reactogenicity and immunogenicity of a cold-adapted recombinant $A / V i c t o r i a / 3 / 75(H 3 N 2)$ live influenza virus candidate vaccine in healthy volunteers. Dev. Biol. Stand. 39, 53-60.

26 Kendal, A.P., Cox, N.J., Galphin, J.C. and Maassab, H.F. (1979) Comparative studies of wildtype and cold-mutant (temperature sensitive) influenza viruses: independent segregation of temperature sensitivity of virus replication from temperature-sensitivity of virion transcriptase activity during recombination of mutant A/Ann Arbor/6/60 with wild-type H3N2 strain. J. Gen. Virol. 44, 443-456.

27 Kendal, A.P., Cox, N.J., Murphy, B.R., Spring, S.B. and Maassab, H.F. (1977) Comparative studies of wild-type and "cold-mutant" (temperature-sensitive) influenza viruses: genealogy of the matrix (M) and non-structural (NS) proteins in recombinant cold adapted H3N2 viruses. J. Gen. Virol. 37, 145-159.

28 Kitayama, T., Togo, Y., Hornick, R.B. and Friedewahl, W.T. (1973) Low-temperature-adapted influenza A2/Ann Arbor/6/60 virus vaccine in man. Infect. Immun. 7, 119-122.

29 Lazar, A., Okabe, N. and Wright, P.F. (1980) Humoral and cellular immune responses of seronegative children vaccinated with a cold adapted influenza $A / H K / 123 / 77$ (H1N1) recombinant virus. Infect. Immun. 27, 862-866.

30 Maassab, H.F. (1967) Adaptation and growth characteristics of influenza virus at $25^{\circ} \mathrm{C}$. Nature (London) 219, 645-646.

31 Maassab, H.F. (1968) Plaque formation of influenza virus at $25^{\circ} \mathrm{C}$. Nature (London) $219,645-$ 646. 
32 Maassab, H.F. (1969) Biologic and immunologic characteristics of cold-adapted influenza virus. J. Immunol. 102, 728-732.

33 Maassab, H.F. (1975) Properties of influenza virus "cold" recombinants. In: Negative Strand Viruses, eds. B.W.J. Mahy and R.D. Barry (Academic Press, New York) Vol. 2, pp. 755-763.

34 Maassab, H.F., Francis, T., Jr., Davenport, F.M., Hennessy, A.V., Minuse, E. and Anderson, G. (1969) Laboratory and clinical characteristics of attenuated strains of influenza virus. Bull. W.H.O. 41, 589-594.

35 Maassab, H.F., Kendal, A.P. and Davenport, F.M. (1972) Hybrid formation of influenza virus at $25^{\circ}$ C. Proc. Soc. Exp. Biol. Med. 139, 768-773.

36 Maassab, H.F., Spring, S.B., Kendal, A.P. and Monto, A.S. (1978) Biologic characteristics of influenza virus recombinants derived at suboptimal temperatures. In: Negative Strand Viruses and the Host Cells, eds. B.W.J. Mahy and R.D. Barry (Academic Press, New York) pp. 731-732.

37 Mackenzie, J.S. (1969) Virulence of temperature-sensitive mutants of influenza virus. Br. Med. J. 3,757-758.

38 Markushin, S.G. and Ghendon, Y.Z. (1973) Genetic classification and biological properties of temperature-sensitive mutants of fowl plague virus. Acta Virol. 17, 369-376.

39 Morris, C.A., Freestone, D.S., Stealey, V.M. and Oliver, P.R. (1975) Recombinant WRL 105 strain live attenuated influenza vaccine. Lancet $2,196-199$.

40 Moritz, A.J., Kunz, C., Hofman, H., Liehl, E., Reeve, P. and Maassab, H.F. (1980) Studies with a cold-recombinant $\mathrm{A} / \mathrm{Victoria} / 3 / 75$ (H3N2) virus. II. Evaluation in adult volunteers. J. Infect. Dis. $142,857-860$.

41 Murphy, B.R., Chanock, R.M., Clements, M.L., Anthony, C.W., Sear, A.J., Cisneros, L.A., Rennels, M.B., Miller, E.H., Black, R.E., Levine, M.M., Betts, R.F., Douglas, R.G., Maassab, H.F., Cox, N.J. and Kendal, A.P. (1981) Evaluation of A/Alaska/6/77 (H3N2) cold-adapted recombinant viruses derived from A/Ann Arbor/6/60 cold-adapted donor virus in adult seronegative volunteers. Infect. Immun. 32, 693-697.

42 Murphy, B.R., Holley, H.P., Berquist, E.J., Levine, M.M., Spring, S.B., Maassab, H.F., Kendal, A.P. and Chanock, R.M. (1979) Cold-adapted variants of influenza $A$ virus: evaluation in adult seronegative volunteers of $A / S c o t l a n d / 840 / 74$ and $A / V i c t o r i a / 3 / 75$ cold-adapted recombinants derived from the cold-adapted A/Ann Arbor/6/60 strain. Infect. Immun. 23, 253-259.

43 Murphy, B.R., Maassab, H.F., Wood, F.T., Jr and Chanock, R.M. (1981) Characterisation of the temperature-sensitive phenotype of the A/Ann Arbor/6/60 cold-adapted virus and its recombinants. Infect. Immun. 32, 960-963.

44 Murphy, B.R., Rennels, M.B., Douglas, G.R., Betts, R.E., Couch, R.B., Cate, T.R., Chanock, R.M., Kendal, A.P., Maassab, H.F., Suwaragool, S., Sotman, S.B., Cisneros, L.A., Anthony, W.C., Nalin, D.R. and Levine, M.M. (1980) Evaluation of influenza A/Hong Kong/123/77 (H1N1) ts-1A2 and cold-adapted recombinant viruses in seronegative adult volunteers. Infect. Immun. $29,348-355$.

45 Murphy, B.R., Spring, S.B., Richman, D.D., Tierney, E.L., Kasel, J. and Chanock, R.M. (1975) Temperature-sensitive mutants of influenza virus. VII. Transfer of the TS-1 [E] lesions to a wildtype influenza $A$ virus with the HON1 surface antigens. Virology $66,533-541$.

46 Murphy, B.R., Tierney, E.L., Barbow, A., Yolken, R.N., Alling, D.W., Holley, H.P., Mayner, R.F. and Chanock, R.M. (1980) Use of the enzyme-linked immunosorbent assay to detect serum antibody responses by volunteers who received attenuated influenza $A$ virus vaccines. Infect. Immun. 29, 342-347.

47 Oxford, J.S., McGeoch, D., Schild, G.C. and Beare, A.S. (1978) Analysis of virion RNA segments and polypeptides of influenza A virus recombinants of defined virulence. Nature 273, 778-779.

48 Oxford, J.S., Schild, G.C., Potter, C.W. and Jennings, R. (1979) The specificity of the antihaemagglutinin antibody response induced in man by inactivated influenza vaccines and by natural infection. J. Hyg. (Camb.) 82, 51-61. 
49 Palese, P. and Ritchey, M.B. (1977) Live attenuated influenza virus vaccines. Strains with temperature-sensitive defects in $\mathrm{P3}$ protein and nucleoprotein. Virology 78, 183-191.

50 Polezhaev, F.I. and Alexandrova, G.I. (1979) The isolation of thermosensitive strains of influenza virus in the period of an epidemic of A/Victoria in 1975-76. Vopr. Virusol. 4, 430.

51 Reeve, P., Gerendas, B., Moritz, A., Liehl, E., Kunz, C., Hofman, H. and Maassab, H.F. (1980) Studies in man with cold-recombinant influenza virus (H1N1) live vaccines. J. Med. Virol. 6, $75-83$.

52 Scholtissek, C. (1979) Influenza virus genetics. Adv. Genet. 20, 1-36.

53 Scholtissek, C. and Bowles, A.L. (1975) Isolation and characterization of temperature-sensitive mutants of fowl plague virus. Virology 67, 576-587.

54 Spring, S.B., Maassab, H.F., Kendal, A.P., Murphy, B.R. and Chanock, R.M. (1977) Cold-adapted variants of influenza virus $A$. I. Comparison of the genetic properties of ts mutants and five coldadapted variants of influenza virus $A$. Virology 77, 337-343.

55 Spring, S.B., Maassab, H.F., Kendal, A.P., Murphy, B.R. and Chanock, R.M. (1977) Cold-adapted variants of influenza A. II. Comparison of the genetic and biological properties of ts mutants and recombinants of the cold-adapted A/AA/6/60 strain. Arch. Virol. 55, 233-246.

56 Spring, S.B., Nusinoff, S.R., Tierney, E.T., Richman, D.D., Murphy, B.R. and Chanock, R.M. (1975) Temperature-sensitive mutants of influenza. VIII. Genetic and biological characterization of TS mutants of influenza virus A (H3N2) and their assignment to complementation groups. Virology $66,542-550$.

57 Stealey, V.M., McCahon, D. and Freestone, D.S. (1975) Preparation and characterisation of live recombinant influenza vaccine. Dev. Biol. Stand. 33, 191-196.

58 Stuart-Harris, C.H. and Schild, G.C. (1976) In: Influenza, the Viruses and the Disease (Littleton, MA) pp. 164-184.

59 Sugiura, A., Tobita, A. and Kilbourne, E.D. (1972) Isolation and preliminary characterization of temperature-sensitive mutants of influenza virus. J. Virol. 10,639-647.

60 Tolpin, M.O., Massicot, J.G., Mullinax, M.G., Kim, H.W., Parrott, R.H., Chanock, R.M. and Murphy, B.R. (1981) Genetic factors associated with loss of the temperature-sensitive phenotype of the influenza A/Alaska/6/77-ts-1A2 recombinant during growth in vivo. Virology 112, 505517.

61 Van Voorthuizen, F., Jens, D. and Saes, F. (1981) Characterization and clinical evaluation of live influenza $A$ vaccine prepared from a recombinant of the A/USSR/92/77(H1N1) and the cold-adapted A/Ann Arbor/6/60(H2N2) strains. Antiviral Res. 1, 107-122.

62 Webster, R.G., Kasel, J.A., Couch, R.B. and Laver, W.G. (1976) Influenza virus subunit vaccines. II. Immunogenicity and original antigenic sin in humans. J. Infect. Dis. 134, 48-58. 